\title{
HEAD AND NECK SQUAMOUS CELL CARCINOMA CELL LINES: ESTABLISHED MODELS AND RATIONALE FOR SELECTION
}

\author{
Charles J. Lin, BA, ${ }^{1}$ Jennifer R. Grandis, MD, ${ }^{1,2}$ Thomas E. Carey, PhD, ${ }^{3}$ \\ Susanne M. Gollin, PhD, ${ }^{1,4,5}$ Theresa L. Whiteside, PhD, ${ }^{1,4,6}$ Wayne M. Koch, MD, ${ }^{7}$ \\ Robert L. Ferris, MD, PhD, ${ }^{1,6}$ Stephen Y. Lai, MD, PhD ${ }^{1}$ \\ ${ }^{1}$ Department of Otolaryngology, School of Medicine, University of Pittsburgh, \\ Pittsburgh, Pennsylvania. E-mail: laisy@upmc.edu \\ ${ }^{2}$ Department of Pharmacology, School of Medicine, University of Pittsburgh, Pittsburgh, Pennsylvania \\ ${ }^{3}$ Department of Otolaryngology, University of Michigan Medical School, Ann Arbor, Michigan \\ ${ }^{4}$ Department of Pathology, School of Medicine, University of Pittsburgh, Pittsburgh, Pennsylvania \\ ${ }^{5}$ Department of Human Genetics, Graduate School of Public Heath, University of Pittsburgh, \\ Pittsburgh, Pennsylvania \\ ${ }^{6}$ Department of Immunology, School of Medicine, University of Pittsburgh, Pittsburgh, Pennsylvania \\ ${ }^{7}$ Department of Otolaryngology, Johns Hopkins University School of Medicine, Baltimore, Maryland
}

Accepted 12 April 2006

Published online 11 August 2006 in Wiley InterScience (www.interscience.wiley.com). DOI: 10.1002/hed.20478

\begin{abstract}
Background. Head and neck squamous cell carcinoma (HNSCC) cell lines are important preclinical models in the search for novel and targeted therapies to treat head and neck cancer. Unlike many other cancer types, a wide variety of primary and metastatic HNSCC cell lines are available. An easily accessible guide that organizes important characteristics of HNSCC cell lines would be valuable for the selection of appropriate HNSCC cell lines for in vitro or in vivo studies.

Methods. A literature search was performed.

Results. Cell growth and culture parameters from HNSCC cell lines were catalogued into tables or lists of selected characteristics. Methods for establishing cancer cell lines and basic cell culture maintenance techniques were reviewed.

Conclusions. A compendium of HNSCC cell line characteristics is useful for organizing the accumulating information regarding cell line characteristics to assist investigators with the devel-
\end{abstract}

Correspondence to: S. Y. Lai

๑ 2006 Wiley Periodicals, Inc. opment of appropriate preclinical models. (C) 2006 Wiley Periodicals, Inc. Head Neck 29: 163-188, 2007

Keywords: head and neck cancer; cell line; characteristics; HNSCC; SCCHN

Head and neck cancers are the eighth most common tumor in the world, accounting for 390,000 new cases of cancer in $2000 .{ }^{1}$ In the United States, there are approximately 30,000 new cases of head and neck cancer each year and 8,000 related deaths. ${ }^{2}$ Head and neck squamous cell carcinoma (HNSCC) accounts for over $90 \%$ of all head and neck cancers. ${ }^{3}$ Unfortunately, the mortality rates for this disease have not improved in the past 40 years despite advances in the delivery of treatment and in surgical reconstruction. Patients diagnosed with HNSCC in the United States have 
a $60 \%$ mortality rate even with standard therapy including radiation, surgery, and/or chemotherapy. ${ }^{4}$ Five-year survival is only $40 \%$, primarily because of invasive spread and regional metastasis. ${ }^{5}$ Head and neck cancers consistently metastasize to the cervical lymph nodes before spreading to distant sites, such as the lung and liver. Current research is focused on understanding the molecular mechanisms of HNSCC development and progression to facilitate the design of novel therapies that may improve survival.

Immortalized cell lines derived from HNSCC tumors have been an invaluable tool for researchers investigating detailed molecular, biochemical, genetic, and immunological properties of head and neck cancer. Advantages of using cell culture include sample homogeneity, cost, and the avoidance of legal and ethical issues associated with animal experimentation. ${ }^{6}$ HNSCC cell lines such as Hep2, Hep3, and $\mathrm{KB}$ were some of the first HNSCC tumor cell lines to be developed as early as the 1950 s. ${ }^{7}$ Establishing HNSCC cell lines has proven challenging. Obstacles include fibroblast overgrowth, long quiescent periods before the cells can be subcultured, and the dependence on feeder layers in primary and secondary cultures. ${ }^{7-9}$ With technical improvements, such as the use of complement-mediated lysis to selectively deplete fibroblasts, mitomycin C-treated mouse 3T3 fibroblast feeder layers, and explant outgrowth followed by differential trypsinization, successful permanent culture of HNSCC cell lines has become more feasible. ${ }^{9-11}$ In fact, more than 300 reported HNSCC cell lines have been established compared with approximately 70,60 , and 10 cell lines derived from breast, colon, and prostate cancers, respectively. ${ }^{12-14}$

\section{ESTABLISHMENT OF HNSCC TUMOR CELL LINE}

The most popular method for establishing a new HNSCC cell line is called the explant culture method. ${ }^{15}$ Establishing a new cancer cell line depends on several factors, with the most important being the method of obtaining the specimen. Surgically removing fresh tumor tissue under aseptic conditions specifically for laboratory use from non-necrotic and uninfected areas greatly increases the success rate of a long-term culture. ${ }^{16}$ The fresh specimen may be treated with a triple antibiotic solution consisting of penicillin, streptomycin, and amphotericin B. Minced tumor fragments are grown in minimal culture medium supplemented with amino acids and serum. As the epithelial cells are growing, fibroblasts are routinely removed either with a cell scraper or by differential trypsinization. Differential trypsinization involves adding trypsin to dislodge the fibroblasts under visualization with an inverted microscope and blocking the trypsin activity with serum-containing medium before the epithelial cells detach. An alternative method using a feeder layer was described by Rheinwald and Beckett. ${ }^{9}$ Instead of placing minced tumor fragments into culture flasks with medium, the feeder layer method uses culture flasks that contain mitomycin C-treated 3T3 mouse-fibroblast feeder cell monolayers. The feeder cells and fibroblasts are then removed with EDTA inoculations and vigorous pipetting.

\section{Cancer cell line maintenance}

For cancer cells to survive and grow in culture, the in vitro environment must be carefully maintained. Three cell culture conditions that influence tumor cell growth will be discussed: culture medium, culture substrate, and physiochemical variables. Nutrition for the cells is supplied by the medium, either with or without serum. The medium contains amino acids, glucose, vitamins, and salts that are necessary to support cellular functions and cell synthesis. More often than not, serum, a chemically undefined mixture of hormones, growth factors, lipids, transport proteins, enzyme cofactors, and attachment factors, is added to culture medium to promote cell growth. The serum is isolated by removing the supernatant from clotted blood, usually from a calf or a fetal bovine source because of its high content of embryonic growth factors. ${ }^{17}$ One needs to weigh the benefits and disadvantages of adding or withholding serum from medium. The major benefit from adding serum is that the proteins and factors in the serum promote faster tumor cell growth; however, these factors and proteins are relatively expensive and not well-defined. They could potentially interfere with experiments that study the effects of specific exogenous growth factors. Additionally, the cell-to-surface interaction is important for cell proliferation. Cancer cell cultures are usually grown as monolayers on polystyrene plastic; however, there are some exceptions, such as the multicellular tumor spheroid and the soft agar models. Tumor cells lose the requirement for anchorage-dependent growth, enabling some cell lines to grow as 3-dimensional spheroids in suspension culture or as suspensions on top of an 
agar medium. These 2 models, which will be discussed later in this review, may reflect in vivo behavior more accurately and are used to investigate specific tumor cell characteristics such as drug response or metastatic potential. Finally, physiochemical variables, such as the $\mathrm{CO}_{2}$ concentration and temperature, need to be maintained within certain limits for optimal cell growth. For human cancer cell lines, the optimal temperature is $37^{\circ} \mathrm{C}$ and the preferred $\mathrm{CO}_{2}$ atmosphere is $5 \% .^{18}$

Once the conditions for cancer cell culture growth are established, it is important to routinely examine the cell cultures both macroscopically and microscopically for cell morphology, cell density, and the presence of contaminants. Macroscopically, the color and turbidity of the culture medium can describe the cell density or presence of microbiological contaminants. For example, the culture medium often turns from pink to yellow when the cells in culture have depleted the nutrients in the medium. Cloudy culture medium often indicates the presence of bacteria or fungi in the culture. Microscopically, it is important to check for signs of cell deterioration such as granularity around the nucleus and cytoplasmic vacuolation. The interval between changing medium and subculturing cells depends on the rate of growth or metabolism of the cancer cells; cultures that grow more rapidly require more frequent changes. When cells occupy the entire surface of a flask, the monolayer culture is considered confluent, and the cells need to be subcultured to reduce the cell density to a level where the cells can achieve optimal growth. Subculturing cells requires the use of proteolytic enzymes such as trypsin (0.01-0.5\%) and/or $1 \mathrm{~m} M$ EDTA to break the cell-to-cell and cell-to-substrate interactions, thereby releasing the cells from the monolayer culture into single cell suspensions. These single cell suspensions can be used for future passages, for cryopreservation, or for setting up experiments.

There is a constant risk of contaminating cell cultures with either microbes or different cancer cell lines. Most of this discussion will address microbial contamination (bacteria, fungus, and mycoplasma) and the methods for monitoring and treating them. Bacterial or fungal contamination is often noticed macroscopically as cloudiness in the medium, fuzzy fungal balls, or microscopically as fine granules. Toxic contamination can cause cultured cells to die and slough off the plate surface, often seen as significant movement under low power. Antibiotics, such as penicillin and streptomycin, may be used to treat unique or irreplaceable cultures that have been contaminated; otherwise, it is recommended that the contaminated cultures be discarded. The concern with using antibiotics prophylactically is developing a source of drug-resistant strains of bacteria that can chronically contaminate the cultures. Mycoplasma are small prokaryotes whose presence in cell cultures cannot be noticed macroscopically or microscopically. Often, these microbes grow insidiously and do not kill the host cells. Despite no apparent influence on cultured cell growth or behavior, the presence of mycoplasma may indeed alter any parameter measured in cell culture or in experimental investigations. ${ }^{19,20}$ By depriving the cultured cells of medium components and degrading specific amino acids, mycoplasma can initiate a range of effects such as altering signal transduction, cytokine and growth factor expression, cancer cell growth, and cell membrane composition. ${ }^{20}$ A popular choice for detecting mycoplasma contamination is with the use of polymerase chain reaction technology to detect mycoplasma-specific sequences. It is a sensitive and specific option for routinely screening growing cell lines or for testing cell lines newly introduced in the laboratory. To salvage irreplaceable cell lines, three groups of antibiotics (tetracycline, macrolides, quinolones) are effective in treating mycoplasma infections. ${ }^{20}$

\section{CHARACTERISTICS OF HNSCC CELL LINES}

The large number of available HNSCC cell lines underscores the importance of categorizing tumor cell line characteristics to help researchers select a cell line that best suits their needs. This review has organized HNSCC cell lines into practical and useful Appendix tables based upon important characteristics. More detailed information regarding specific cell lines and models can be found in the primary references.

Tumor Cell Line Name and Patient Demographics. Appendix Table A1 includes general characteristics and procurement information, such as tumor cell line name, patient data, and TNM stage. The cell lines that are available from the American Type Culture Collection (ATCC) are noted. The table also provides primary references for the cell lines and additional references focused upon chromosomal and molecular genetic characteristics. The genetics references are not intended 
to be exhaustive, but provide researchers a starting point for further investigation.

HNSCC usually arises in patients with a history of tobacco and/or alcohol use, suggesting that alcohol and the carcinogens found in tobacco synergistically enhance the development of mutations responsible for HNSCC. Furthermore, areas of the upper aerodigestive tract, which are exposed to the highest levels of carcinogens in smokers, also experience high frequencies of HNSCC, further suggesting that changes at the chromosomal level lead to tumorigenesis. ${ }^{21,22}$ As further evidence of the genetic basis for HNSCC, other malignancies such as esophageal and lung cancers, which share a common carcinogenic association to tobacco, have demonstrated deletions in chromosome $3 \mathrm{p}^{23-30}$ In fact, Cowan et al observed that 6 of 10 HNSCC cell lines demonstrated deletions in regions of chromosome $3 p$ that contain tumor suppressor genes. ${ }^{29,31}$ Other studies investigating chromosomal aberrations have reported $11 \mathrm{q} 13$ amplification in $20 \%$ to $50 \%$ of HNSCC cases and its association with poor clinical prognosis and increased metastasis. ${ }^{32-34}$ The 11q13 locus contains genes that code for cyclin D1, 2 members of the fibroblast growth factor family, and cortactin. Overexpression of cyclin D1 and cortactin may play a role in HNSCC tumor progression. ${ }^{29,35-38}$ Mutations of the TP53 tumor suppressor gene are a well-recognized step in carcinogenesis. Specific TP53 genetic alterations in HNSCC cell lines have been characterized (Appendix Table A2). Chromosomal alterations and instability enable the multistep process of genetic changes in HNSCC. ${ }^{29,39-41}$ Whether the disruption is a loss of function of tumor suppressor genes or overexpression of oncogenes, or an alteration of chromosomal constitution, genetic changes are at the foundation of the series of changes that lead to rapid cell growth, tumor proliferation, and metastatic invasion. The chromosomal and genetic heterogeneity present in the primary tumor remain evident in cell lines despite continued passage in vitro. Further investigations to elucidate the relationship between genetic alterations at the cytogenetic and molecular level with tumor behavior and clinical outcome will continue to be critical. $^{29,31}$

Site of Origin of Tumor Cell Lines. By organizing cell lines according to the site of origin, site-specific characteristics of HNSCC may be investigated with the possibility of developing more specific and targeted therapies. In the past, head and neck cancer has been studied as an aggregate of tumors from different sites in the upper aerodigestive tract. Appendix Table A3 organizes the tumor cell lines on the basis of the anatomic site of origin. The sites of origin are divided into 7 categories: facial skin, nasal/paranasal sinus, oral cavity, oral pharynx, hypopharynx, pharynx, and larynx. As shown in Appendix Table A3, most of the HNSCC cell lines are derived from tumors that either originated from the oral cavity or the larynx.

Doubling Times of Tumor Cell Lines. Doubling times are an important parameter used to measure the cellular response to experimental changes in culture conditions such as nutrient concentrations, hormones, or drugs ${ }^{42}$ (Appendix Table A4). From a practical standpoint, knowledge of doubling times facilitates the daily maintenance of HNSCC cell cultures. Experiments can be planned so that cells will be in log phase when they are treated with reagents. The standard cycle of cell growth begins with negligible growth during the lag phase. After trypsinization, the cells adapt to the new environment by replacing elements of the glycocalyx lost during trypsinization, attaching to the substrate and spreading out. Following the lag phase, cells proceed into exponential growth during log phase. This is the optimal time for sampling because the population is most uniform and cell viability is high. The doubling time is measured during this phase. Cells are counted during the log phase, and the average doubling time is determined by plotting the cell counts as a function of time. ${ }^{43}$ Another method for measuring doubling time is to calculate the time necessary for the cells to increase twofold in the middle of the log phase. ${ }^{42}$ Toward the end of the log phase, adherent cells become confluent, cell division slows, and steady-state equilibrium between cell growth and cell death is achieved in stationary phase. In normal cells, a phenomenon termed contact inhibition has been observed when the cells become confluent during the stationary phase, suggesting that direct contact between neighboring cells reduces cell motility, membrane ruffling, and cell growth. However, HNSCC cell lines with regular culture medium replenishment will continue to proliferate beyond confluence to form multilayers of cells. The decline phase begins when nutrients are depleted and toxic by-products of metabolism accumulate leading to cell death. ${ }^{42,44}$

In Vivo Xenograft Growth of Tumor Cell Lines. Tumor cell lines or explants introduced as xenografts in mice can potentially model complex interactions 
between the tumor and its host. Despite limitations, there is no current technology or in vitro assay that can predict the activity of antineoplastic drugs as accurately or demonstrate the tumorigenic and metastatic properties of tumors as fully as xenograft animal models. Appendix Table A5 catalogues the HNSCC cell lines that have grown as xenografts in mice. The athymic nude mouse was first described by Pantelouris in $1968 .^{45}$ In 1969, Polvsen and Rygaard were the first to xenograft a human colon adenocarcinoma into a nude mouse, and 3 years later, Polvsen and Rygaard were the first to transplant human tumor cells into the nude mouse model. ${ }^{46,47}$ In 1984, Braakhuis et $\mathrm{al}^{48}$ demonstrated that the nude mouse xenograft model could be used to study head and neck cancer by implanting 130 human head and neck biopsy explants into the subcutaneous tissue of nude mice.

The most commonly used immunodeficient mouse model to study head and neck cancer is the athymic nude mouse, which carries a homozygous $n u$ mutation on mouse chromosome 11 leading to thymic dysgenesis. ${ }^{46}$ While the primary immune defect of these mice is T-cell deficiency to prevent graft rejection, the athymic nude mouse is not completely immunodeficient. Although, functional T lymphocytes are effectively absent, B cells, natural killer (NK) cells, and macrophages are still present. Nevertheless, the nude mouse is more immunodeficient than animals that are rendered immunodeficient by artificial thymectomy or by other means of artificial immunosuppression. The benefits of using athymic nude mice include the following: thorough characterization and wide use; lack of hair that allows for visualization of subcutaneously xenografted tumors; immunodeficiency severe enough to support growth of wide range of tumor cells; and availability on different genetic backgrounds. ${ }^{49}$ However, the nude mice retain normal levels of NK cells and macrophages. To eliminate NK cell activity and improve tumor establishment, nude mice can be pretreated with cyclophosphamide. ${ }^{50}$ A less commonly used immunodeficient mouse model is the severe combined immunodeficiency (SCID) mouse. The benefit of using a SCID mouse is that the more severe immunodeficiency resulting in arrested T-cell and B-cell development allows for a higher percentage of engraftment, more enhanced tumor growth, and less tumor regression. ${ }^{49}$ However, the disadvantages of SCID mice are that they experience a high incidence of thymic lymphomas, which may shorten their lifespan, and their severe immunodeficiency makes them harder to maintain. ${ }^{49,51}$
Several considerations need to be appreciated regarding the mouse xenograft model. ${ }^{52}$ The xenograft in the mouse can be derived from either a tumor cell line or a patient biopsy explant. Tumor cell lines are histologically homogenous and undifferentiated, which ensures experimental uniformity and reproducibility. A drawback to using tumor cell lines is the concern that as they grow in vitro, they adapt to the culture environment and may develop genetic and phenotypic differences from the original tumor. The benefit of using biopsy explants is that they conserve morphological and molecular markers characteristics better than tumor cell lines; however, the disadvantage is the heterogeneous cell population found in the biopsy specimen and the difficulty associated with xenografting an explant. The site of xenograft implantation is also an important consideration. Most investigators implant HNSCC tumors into the subcutaneous tissue of the abdomen, nape of the neck, or the flank because of the relative ease in monitoring tumor growth and size; however, the subcutaneous implants show a benign growth pattern. Studies with tumor cells implanted into the subcutaneous tissue had difficulty demonstrating any significant invasion of surrounding tissues or metastatic activity. ${ }^{47,48,53,54}$ Patients with head and neck cancer often have tumors that aggressively invade local surrounding tissues, so the subcutaneous model has its limitations. Orthotopic xenografts in the floor of mouth have been able to produce tumors that mimic histopathologic growth in the head and neck cancer patient, including invasion into surrounding tissues and spread to cervical lymph nodes.$^{55,56}$ Despite the recent developments of the murine model in head and neck cancer, it is important to recognize the limitations of the mouse xenograft model. Immunodeficient mouse strains have increased susceptibility to viral and bacterial infections, which limits the life span of the xenograft mouse to 4-6 months. In addition, immunodeficient mice have a different immunobiology when compared with the human host, which may result in different mechanisms and rates of tumor progression as well as treatment responses. Although beyond the scope of this review, the development of novel transgenic, knock-out and/or knock-in mice may provide more realistic models of human HNSCC in the setting of an intact immune system.

\section{Tumor Cell Line Growth in Nonmonolayer Cul-} tures. Soft agar growth demonstrates anchorage-independent proliferation potential, a hallmark of transformed cancer cells. Normally, non- 
neoplastic cells require cell-matrix anchorage to survive; otherwise, a suspension-induced apoptosis known as anoikis occurs. Heterodimeric transmembrane cell surface receptors known as integrins bind to components of the extracellular matrix (ECM), and numerous studies have shown the disruption of these interactions lead to anoikis. ${ }^{57-62}$ However, cancer cells have less stringent requirements for extracellular matrix adhesion, allowing them to resist anoikis and survive in an anchorage-independent manner. This property enables cancer cells to extravasate into lymphatic channels or blood vessels and invade a distant organ. Growth on soft agar becomes a reliable measure of the metastatic capability of tumor cells. Ten HNSCC cell lines have been reported to grow on soft-agar: $\mathrm{HN}-1,{ }^{8} \mathrm{HN}-2,{ }^{8} \mathrm{UM}-\mathrm{SCC}-11 \mathrm{~A},{ }^{63}$ UM-SCC-14C, ${ }^{64}$ UM-SCC-38, ${ }^{64}$ TR126, ${ }^{65}$ TR131, ${ }^{65}$ TR146, ${ }^{65}$ MDA-183, ${ }^{23}$ and MDA-1483. ${ }^{23}$ One challenge with this methodology is that most HNSCC cell lines do not grow in soft agar.

Spheroids offer a useful model of solid tumors because monolayer cultures lack the cell-to-cell interactions characteristic of tumors in vivo. ${ }^{66}$ Spheroids are composed of an outer layer of proliferating cells, an inside layer of quiescent cells, and an inner core of necrotic cells. This arrangement reflects the growth pattern on solid tumors in vivo, with proliferating cells found closest to a nutrient and oxygen supply, quiescent cells found slightly farther, and necrotic cells found the farthest from capillaries. ${ }^{67-75}$ There are 2 methods for culturing spheroids. The most popular approach involves the use of spinner flasks. Monolayer cell cultures are trypsinized and seeded in growth medium within spinner flasks. Rotation is achieved by spinning a stir bar in the spinner flask. Factors that affect spheroid formation include the type of cells, cell density at seeding, the rotation speed, the type of culture medium, and the incubation time. The advantage of using spinner flask cultures is the large number of spheroids formed from large-volume cultures and the considerable size of the spheroids. ${ }^{67,76}$ Another method for forming spheroids is to use agar overlay cultures as first described by Yuhas. ${ }^{77}$ Tumor cells obtained from confluent monolayer cultures are trypsinized into single-cell suspensions. These suspensions are seeded in a stationary, nonadherent mixture of complete growth medium and agarose. ${ }^{67}$ When the spheroids are ready for experiments, it is critically important to select spheroids of the same size since a slight difference in diameter can result in a dramatic volume difference.
Size uniformity can be achieved with the use of a Pasteur pipette and a low-power microscope, or for rapid harvesting of spheroids, the cultures may be filtered through a nylon sieve of decreasing mesh size to segregate spheroids, based on size and leaving the largest spheroids on top. ${ }^{67}$ Eleven cell lines have been reported to cluster into 3dimensional spheroidal cultures: $\mathrm{Hep} 2,{ }^{78} \mathrm{FaDu},{ }^{79}$ HN- $1,{ }^{80,81}$ UM-SCC-22B, ${ }^{78}$ UM-SCC-30, ${ }^{78}$ CAL27, ${ }^{82}$ MDA-1483, ${ }^{23,83}$ MDA-886LN, ${ }^{83}$ MDA-686LN, ${ }^{83}$ T1/CUHK, ${ }^{84}$ and T2/CUHK. ${ }^{84}$

Spheroids may also be cultured from biopsy specimens and such cultures demonstrate ploidy stability suggesting that biopsies cultured in vivo maintain the cellular complexity of tumors in vivo. ${ }^{85}$ Spheroid cultures derived from biopsy specimens do not experience the problematic clonal evolution of tumor cell subpopulations that has been attributed to the passage of monolayer cultures grown from biopsy specimens. ${ }^{86}$ After a cell line has been passaged several times, there have been questions about its semblance to the original tumor. ${ }^{85}$ However, genetic and molecular cytogenetic data show that HNSCC cells in culture closely resemble those in the primary tumors. ${ }^{87,88}$

A 3-dimensional spheroidal culture may be a better representation of the in vivo cellular complexity and heterogeneity found in the microenvironment of a tumor nodule than a monolayer culture. The 3-dimensional arrangement reflects several characteristics of tumor cells in vivo such as the irregular distribution of oxygen and nutrients found in tumor cells in vivo and cellular subpopulations of proliferating, quiescent, and necrotic cells. A model that better mimics tumor heterogeneity and intercellular contact should exhibit a more representative response to drug therapies. For example, studies using spheroid cell cultures have shown large variations in radiation and drug sensitivity, similar to those found with tumors in vivo. ${ }^{74,89-94}$ Finally, spheroidal cultures are less affected by the culture conditions because of reduced cell-to-cell interactions. ${ }^{67} \mathrm{~A}$ limiting factor to the use of tumor spheroids lies in the difficulty of establishing cell lines that can associate into spheroid clusters. Although both normal and transformed human cells may aggregate, only certain tumor cells will grow as spheroids. This review lists 11 reported HNSCC cell lines out of almost 300 total cell lines that can reassociate into spheroidal clusters. Across a wide range of different cancer types, only 5 of 22 human tumor xenografts and 16 of 27 tumor cell lines formed spheroids. ${ }^{68,95}$ 


\section{SUMMARY}

Head and neck cancer remains a significant public health concern. Despite current surgical treatments and adjunctive chemoradiation therapy, 5 -year survival rates remain below $50 \%$. This has prompted a greater need for investigating novel and targeted therapies. The use of HNSCC cell lines will be vital for these preclinical developments. Although the literature characterizing HNSCC cell lines is abundant, an easily accessible reference that organizes these data for researchers interested in selecting cell lines is necessary. This review provides a detailed catalogue of HNSCC cell line characteristics that will assist new and experienced investigators in their selection of appropriate preclinical models for further understanding head and neck tumor biology and therapeutic mechanisms.

Acknowledgments. This work was supported by a Howard Hughes Medical Institute Medical Research Training Fellowship (CJL) and the Flight Attendant Medical Research Institute Young Clinical Scientist Award (SYL).

\section{REFERENCES}

1. Stewart BW, Kleihues P, editors. Cancer facts \& figures. In World Health Organization: World cancer report. London: IACR Press; 2003.

2. Jemal A, Murray T, Ward E, et al. Cancer statistics, 2005. CA Cancer J Clin 2005;55:10-30.

3. Batsakis J. Tumors of the head and neck. Baltimore: Williams and Wilkins; 1979.

4. Dimery IW, Hong WK. Overview of combined modality therapies for head and neck cancer. J Natl Cancer Inst 1993;85:95-111.

5. Vikram B. Failure at distant sites following multimodality treatment for advanced head and neck cancer. Head Neck Surg 1984;6:730-733.

6. Freshney RI. Culture of animal cells, 3rd ed. New York: Wiley-Liss; 1994. pp 1-7.

7. Moore A, Sabachewsky L, Toolan H. Culture characteristics of four permanent lines of human cancer cells. Cancer Res 1955;15:598-602.

8. Easty D, Easty G, Carter R, Monaghan P, Butler L. Ten human carcinoma cell lines derived from squamous carcinomas of the head and neck. Br J Cancer 1981;43: 772-785.

9. Rheinwald J, Beckett M. Tumorigenic keratinocyte lines requiring anchorage and fibroblast support cultured from human squamous cell carcinomas. Cancer Res 1981;41:1657-1663.

10. Edwards P, Easty D, Foster C. Selective culture of epithelioid cells from a human squamous carcinoma using a monoclonal antibody to kill fibroblasts. Cell Biol Int Rep 1980;4:917-922.

11. Krause C, Carey T, Ott R, Hurbis C, McClatchey K, Regezi J. Human squamous cell carcinoma. Establishment and characterization of new permanent cell lines. Arch Otolaryngol 1981;107:703-710.
12. Brattain MG, Willson J, Kolerba A, Patil S, Venkateswarlu S. Colorectal cancer. In: Masters JR, Palsson B, editors. Human cell culture, Vol 2, cancer cell lines, Part 2. Norwell: Kluwer Academic Publishers; 2002. pp 293-304.

13. Kozlowshi J, Sensibar JA. Prostate cancer. In: Masters JR, Palsson B, editors. Human cell culture, Vol 2, cancer cell lines, Part 2. Norwell: Kluwer Academic Publishers; 2002. pp 305-332.

14. Sutherland R, Watts CK, Lee CS, Musgrove EA. Breast cancer. In: Masters JR, Palsson B, editors. Human cell culture, Vol 2, cancer cell lines, Part 2. Norwell: Kluwer Academic Publishers; 2002. pp 79-106.

15. Carey T. Head and neck tumor cell lines. In: Hay RKM, Park JG, Gazdar A, editors. Atlas of human tumor cell lines. Orlando: Academic Press. 1994. pp 79-120.

16. Lansford C, Grenman R, Bier H, et al. Head and neck cancers. In: Masters JR, Palsson B, editors. Human cell culture, Vol 2, cancer cell lines, Part 2. Dordrecht: Kluwer Academic Press; 1999. pp 185-255.

17. Butler M. Supplements to basal media. In: Butler M, Dawson M, editors. Cell culture. Oxford: Academic Press; 1992. pp 107-134.

18. Langdon S. Basic principles of cancer cell culture. In: Langdon S, editor. Cancer cell culture: methods and protocols. Totowa: Humana Press; 2004. pp 3-15.

19. Barile MF, Rottem S. Mycoplasmas in cell culture. In: Kahani I, Adoni A, editors. Rapid diagnosis of mycoplasmas. New York: Plenum; 1993. pp 155-193.

20. Uphoff C, Drexler H. Elimination of mycoplasma from infected cell lines using antibiotics. Totowa: Humana Press; 2004. pp 327-334.

21. Blot WJ, McLaughlin JK, Winn DM, et al. Smoking and drinking in relation to oral and pharyngeal cancer. Cancer Res 1988;48:3282-3287.

22. Franceschi S, Talamini R, Barra S, et al. Smoking and drinking in relation to cancers of the oral cavity, pharynx, larynx, and esophagus in northern Italy. Cancer Res 1990;50:6502-6507.

23. Sacks PG, Parnes SM, Gallick GE, et al. Establishment and characterization of two new squamous cell carcinoma cell lines derived from tumors of the head and neck. Cancer Res 1988;48:2858-2866.

24. Whang-Peng J, Banks-Schlegel SP, Lee EC. Cytogenetic studies of esophageal carcinoma cell lines. Cancer Genet Cytogenet 1990;45:101-120.

25. Latif F, Fivash M, Glenn G, et al. Chromosome 3p deletions in head and neck carcinomas: statistical ascertainment of allelic loss. Cancer Res 1992;52:14511456.

26. Heo DS, Snyderman C, Gollin SM, et al. Biology, cytogenetics, and sensitivity to immunological effector cells of new head and neck squamous cell carcinoma lines. Cancer Res 1989;49:5167-5175.

27. Maestro R, Gasparotto D, Vukosavljevic T, Barzan L, Sulfaro S, Boiocchi M. Three discrete regions of deletion at $3 \mathrm{p}$ in head and neck cancers. Cancer Res 1993;53:5775-5779.

28. Whang-Peng J, Kao-Shan CS, Lee EC, et al. Specific chromosome defect associated with human small-cell lung cancer; deletion 3p(14-23). Science 1982;215:181182.

29. Gollin SM. Chromosomal alterations in squamous cell carcinomas of the head and neck: window to the biology of disease. Head Neck 2001;23:238-253.

30. Virgilio L, Shuster M, Gollin SM, et al. FHIT gene alterations in head and neck squamous cell carcinomas. Proc Natl Acad Sci U S A 1996;93:9770-9775.

31. Cowan JM, Beckett MA, Ahmed-Swan S, Weichselbaum RR. Cytogenetic evidence of the multistep origin of head and neck squamous cell carcinomas. J Natl Cancer Inst 1992;84:793-797. 
32. Muller D, Millon R, Lidereau R, et al. Frequent amplification of 11q13 DNA markers is associated with lymph node involvement in human head and neck squamous cell carcinomas. Eur J Cancer B Oral Oncol 1994;30:113-120.

33. Rodrigo JP, Suarez C, Gonzalez MV, et al. Variability of genetic alterations in different sites of head and neck cancer. Laryngoscope 2001;111:1297-1301.

34. Meredith SD, Levine PA, Burns JA, et al. Chromosome 11q13 amplification in head and neck squamous cell carcinoma. Association with poor prognosis. Arch Otolaryngol Head Neck Surg 1995;121:790-794.

35. Muller D, Millon R, Velten M, et al. Amplification of 11q13 DNA markers in head and neck squamous cell carcinomas: correlation with clinical outcome. Eur J Cancer 1997;33:2203-2210.

36. Namazie A, Alavi S, Olopade OI, et al. Cyclin D1 amplification and p16(MTS1/CDK4I) deletion correlate with poor prognosis in head and neck tumors. Laryngoscope 2002;112:472-481.

37. Patel AM, Incognito LS, Schechter GL, Wasilenko WJ, Somers K D. Amplification and expression of EMS-1 (cortactin) in head and neck squamous cell carcinoma cell lines. Oncogene 1996;12:31-35.

38. Huang X, Gollin SM, Raja S, Godfrey TE. High-resolution mapping of the 11q13 amplicon and identification of a gene, TAOS1, that is amplified and overexpressed in oral cancer cells. Proc Natl Acad Sci U S A 2002;99: 11369-11374.

39. Gollin SM. Mechanisms leading to chromosomal instability. Semin Cancer Biol 2005;15:33-42.

40. Reshmi SC, Saunders WS, Kudla DM, Ragin CR, Gollin SM. Chromosomal instability and marker chromosome evolution in oral squamous cell carcinoma. Genes Chromosomes Cancer 2004;41:38-46.

41. Saunders WS, Shuster M, Huang X, et al. Chromosomal instability and cytoskeletal defects in oral cancer cells. Proc Natl Acad Sci U S A 2000;97:303-308.

42. Freshney RI. Culture of animal cells. New York: WileyLiss; 1994. pp 279-282.

43. Pekkola-Heino K, Joensuu H, Klemi P, Grenman R. Relation of DNA ploidy and proliferation rate to radiation sensitivity in squamous carcinoma cell lines. Arch Otolaryngol Head Neck Surg 1994;120:750-754.

44. Dawson M. Initiation and maintenance of cultures. In: Butler M, Dawson M, editors. Cell culture. Oxford: BIOS Scientific Publishers; 1992. p 35.

45. Pantelouris E. Absence of thymus in a mouse mutant. Nature 1968;217:270, 271.

46. Rygaard J, Povlsen C. Heterotransplantation of a human malignant tumour to 'nude' mice. Acta Pathol Micobiol Scand 1969;77:758-760.

47. Povlsen C, Rygaard J. Heterotransplantation of human epidermoid carcinomas to the mouse mutant nude. Acta Pathol Microbiol Scand 1972;80:713-717.

48. Braakhuis B, Sneeuwloper G, Snow G. The potential of the nude mouse xenograft model for the study of head and neck cancer. Arch Otorhinolaryngol 1984;239:6979 .

49. Immunodeficient model selection: choosing a nude, scid or Rag1 strain. JAX Communication 2000:1-4.

50. Gorelik E, Herberman R. Role of natural killer (NK) cells in the control of tumor growth and metastatic spread. In: Herberman R, editor. Cancer immunology: innovative approaches to therapy. New York: Kluwer Academic Publishers; 1986. pp 151-176.

51. Clarke R. Human tumours in animal hosts. In: Alison M, editor. Cancer handbook. New York: Wiley; 2005. pp 913-922.

52. Kelland LR. Of mice and men: values and liabilities of the athymic nude mouse model in anticancer drug development. Eur J Cancer 2004;40:827-836.
53. Sharkey FE, Fogh J. Metastasis of human tumors in athymic nude mice. Int J Cancer 1979;24:733-738.

54. Sordat M, Merenda C, Carrel S, Invasive growth and dissemination of human solid tumors and malignant cell lines grafted subcutaneously to newborn nude mice, in Proceedings of Second Workshop on Nude Mice. Tokyo (1977)313-325.

55. Dinesman A, Haughey B, Gates GA, Aufdemorte T, Von Hoff DD. Development of a new in vivo model for head and neck cancer. OtolaryngolHead Neck Surg 1990; 103(5 Pt 1):766-774.

56. O’Malley BW Jr, Cope KA, Johnson CS, Schwartz MR. A new immunocompetent murine model for oral cancer. Arch Otolaryngol Head Neck Surg 1997;123:20-24.

57. Brooks PC, Montgomery AM, Rosenfeld M, et al. Integrin $\alpha$ v $\beta 3$ antagonists promote tumor regression by inducing apoptosis of angiogenic blood vessels. Cell 1994; 79:1157-1164.

58. Fukai F, Mashimo M, Akiyama K, Goto T, Tanuma S, Katayama T. Modulation of apoptotic cell death by extracellular matrix proteins and a fibronectin-derived antiadhesive peptide. Exp Cell Res 1998;242:92-99.

59. Kerr JS, Wexler RS, Mousa SA, et al. Novel small molecule $\alpha \mathrm{v}$ integrin antagonists: comparative anti-cancer efficacy with known angiogenesis inhibitors. Anticancer Res 1999;19(2A):959-968.

60. Liu W, Ahmad SA, Reinmuth, N, et al. Endothelial cell survival and apoptosis in the tumor vasculature. Apoptosis 2000;5:323-328.

61. Mitjans F, Meyer T, Fittschen C, et al. In vivo therapy of malignant melanoma by means of antagonists of $\alpha \mathrm{v}$ integrins. Int J Cancer 2000;87:716-723.

62. Grossmann J. Molecular mechanisms of "detachmentinduced apoptosis-Anoikis". Apoptosis 2002;7:247-260.

63. Grenman R, Burk D, Virolainen E, et al. Clonogenic cell assay for anchorage-dependent squamous carcinoma cell lines using limiting dilution. Int J Cancer 1989;44: 131-136.

64. Coleman SC, Stewart ZA, Day TA, Netterville JL, Burkey BB, Pietenpol JA. Analysis of cell-cycle checkpoint pathways in head and neck cancer cell lines: implications for therapeutic strategies. Arch Otolaryngol Head Neck Surg 2002;128:167-176.

65. Rupniak HT, Rowlatt C, Lane EB, et al. Characteristics of four new human cell lines derived from squamous cell carcinomas of the head and neck. J Natl Cancer Inst 1985;75:621-635.

66. Freshney RI. Culture of animal cells, 3rd ed. New York: Wiley-Liss; 1994. pp 71-103.

67. Bjerkvig R. Spheroid culture in cancer research. Boca Raton: CRC Press; 1992. pp 3-18.

68. Carlsson J, Nilsson K, Westermark B, et al. Formation and growth of multicellular spheroids of human origin. Int J Cancer 1983;31:523-533.

69. Durand RE. Multicell spheroids as a model for cell kinetic studies. Cell Tissue Kinet 1990;23:141-159.

70. Franko AJ, Sutherland RM. Oxygen diffusion distance and development of necrosis in multicell spheroids. Radiat Res 1979;79:439-453.

71. Freyer JP. Role of necrosis in regulating the growth saturation of multicellular spheroids. Cancer Res 1988; 48:2432-2439.

72. Griffon G, Marchal C, Merlin JL, Marchal S, Parache RM, Bey P. Radiosensitivity of multicellular tumour spheroids obtained from human ovarian cancers. Eur J Cancer 1995;31A:85-91.

73. Schwachofer JH, Acker H, Crooijmans RP, et al. Oxygen tensions in two human tumor cell lines grown and irradiated as multicellular spheroids. Anticancer Res 1991;11:273-279.

74. Sutherland R. Cell and environment interations in tumor microregion: the multicell spheroid model. Science 1988;240:177-184. 
75. Sutherland RM, Eddy HA, Bareham B, Reich K, Vanantwerp D. Resistance to adriamycin in multicellular spheroids. Int J Radiat Oncol Biol Phys 1979;5: $1225-1230$.

76. Moscona AA. Cell suspension from organ rudiments of chick embryos. Exp Cell Res 1952;3:535-539.

77. Yuhas J, Martinez A, Ladman A. A simplified methods for the production and growth of multicellular tumor spheroids. Cancer Res 1977;37:3639-3643.

78. Jetten AM, Kim JS, Sacks PG, et al. Inhibition of growth and squamous-cell differentiation markers in cultured human head and neck squamous carcinoma cells by $\beta$-all-trans retinoic acid. Int J Cancer 1990;45: 195-202.

79. Tupper J, Greco O, Tozer GM, Dachs GU. Analysis of the horseradish peroxidase/indole-3-acetic acid combination in a three-dimensional tumor model. Cancer Gene Ther 2004;11:508-513.

80. Schwachofer JH, Crooijmans RP, Hoogenhout J, Kal HB, Theeuwes AG. Effectiveness of cis-platin and carboplatin in the chemotherapy of squamous cell carcinoma grown as multicellular spheroids. Anticancer Res 1990;10:805-811.

81. Schwachofer JH, Crooijmans RP, van Gasteren J, Hoogenhout J, Jerusalem CR, Kal HB. Sublethal damage repair and radiosensitivity of human squamous cell carcinoma cells grown with different culture techniques. Br J Radiol 1989;62:1084-1088.

82. Griffon-Etienne G, Merlin JL, Marchal C. In vitro evaluation of Taxol combined with radiations in human squamous cell carcinoma spheroids. Cancer Lett 1996;109: 23-32.

83. Sturgis EM, Sacks PG, Masui H, Mendelsohn J, Schantz SP. Effects of antiepidermal growth factor receptor antibody 528 on the proliferation and differentiation of head and neck cancer. Otolaryngol Head Neck Surg 1994;111:633-643.

84. Chew EC, King WW, Hou HJ, Yam HF. Establishment and characterization of two new cell lines derived from squamous cell carcinoma of the tongue in Chinese patients. Anticancer Res 1992;121:627-633.

85. Bjerkvig R. Spheroid culture in cancer research. Boca Raton: CRC Press; 1992. pp 41-58.

86. Shapiro J, Shapiro W. The subpopulations and isolated cell types of freshly resected high grade human gliomas: their influence on the tumor's evolution in vivo and behavior and therapy in vitro. Cancer Metastasis Rev 1985;4:107124.

87. Worsham MJ, Wolman SR, Carey TE, Zarbo RJ, Benninger MS, Van Dyke DL. Chromosomal aberrations identified in culture of squamous carcinomas are confirmed by fluorescence in situ hybridisation. Mol Pathol 1999;52:42-46.

88. Ragin CC, Reshmi SC, Gollin SM. Mapping and analysis of HPV16 integration sites in a head and neck cancer cell line. Int J Cancer 2004;110:701-709.

89. Carlsson J, Nederman T. Tumor spheroid technology in cancer therapy research. Eur J Cancer Clin Oncol 1989; 25:1127-1133.

90. Durand R. Variable radiobiological responses of spheroids. Radiat Res 1980;81:85-99.

91. Mueller-Klieser W. Multicellular spheroids. A review on cellular aggregates in cancer research. J Cancer Res Clin Oncol 1987;113:101-122.

92. Mederman T. Growth of tumor cells as multicellular spheroids and antitumor drug evaluation. In: Dendy PP, Hall BT, editors. Human tumor drug testing in vitro. London: Academic Press; 1983. p 147.

93. Sutherland R. Importance of critical metabolites and cellular interactions in the biology of microregions of tumors. Cancer 1986;58:1668-1680.

94. Sutherland R, Durand R. Radiation response of multicell spheroids-an in vitro tumor model. Curr Top Radiat Res Q 1976;11:87-139.

95. Jones AC, Stratford IJ, Wilson PA, Peckham MJ. In vitro cytotoxic drug sensitivity testing of human tumour xenografts grown as multicellular tumour spheroids. $\mathrm{Br}$ J Cancer 1982;46:870-879. 
APPENDIX

Table A1. Tumor cell line name and patient demographics.

\begin{tabular}{|c|c|c|c|c|}
\hline Cell line & Sex & TNM stage & Reference & Genetics references \\
\hline Hep2* & M & - & 1,2 & - \\
\hline Hep3 & M & - & 1,2 & - \\
\hline $\mathrm{KB}^{\star}$ & M & - & 3 & - \\
\hline RPMI 2650 & - & - & 4 & - \\
\hline Detroit $562^{*}$ & $\mathrm{~F}$ & - & 5 & - \\
\hline $\mathrm{FaDu}^{*}$ & M & - & 6 & - \\
\hline SW579* & M & - & 7 & - \\
\hline$A-253^{*}$ & $M$ & - & 8 & - \\
\hline T3M-1 & M & - & 9 & 9 \\
\hline HLac78 & - & T2N2M0 & 10,11 & 11 \\
\hline HLac79 & - & - & 11 & 11 \\
\hline HSmC78 & - & T2N2MO & 10,11 & 11 \\
\hline $\mathrm{HPaC} 79$ & - & - & 11 & - \\
\hline $\mathrm{MC}$ & $\mathrm{F}$ & - & 12 & - \\
\hline $\mathrm{HN}-1$ & M & T2N1M0 & 13 & 13,14 \\
\hline $\mathrm{HN}-2$ & M & T3NOMO & 13 & 13,14 \\
\hline $\mathrm{HN}-3$ & M & T3NOMO & 13 & 13,14 \\
\hline $\mathrm{HN}-4$ & M & T2NOMO & 13 & 13 \\
\hline $\mathrm{HN}-5$ & M & T2NOMO & 13 & 14 \\
\hline $\mathrm{HN}-6$ & M & T2NOMO & 13,15 & 14 \\
\hline $\mathrm{HN}-6 \mathrm{Rr}$ & M & - & 15 & - \\
\hline HN-6nl & M & - & 15 & - \\
\hline HN-6n2 & M & - & 15 & 14 \\
\hline $\mathrm{HN}-7$ & M & T2NOMO & 13 & - \\
\hline $\mathrm{HN}-8$ & M & T2NOMO & 13 & - \\
\hline HN-9 & $\mathrm{F}$ & T2NOMO & 13 & - \\
\hline $\mathrm{HN}-10$ & M & T2NOMO & 13 & - \\
\hline UM-SCC-1 & M & T2NOMO & 16 & 7 \\
\hline UM-SCC-2 & $\mathrm{F}$ & T2NOMO & 16 & 17 \\
\hline UM-SCC-3 & $\mathrm{F}$ & T1NOMO & 16 & 17,18 \\
\hline UM-SCC-4 & $\mathrm{F}$ & T3N2aM0 & 19 & 17 \\
\hline UM-SCC-5 & M & T2N1M0 & 19 & $17,18,20$ \\
\hline UM-SCC-6 & M & T2NOMO & 19 & 17,18 \\
\hline UM-SCC-7 & M & T2N1M0 & 19 & 17,18 \\
\hline UM-SCC-8 & $\mathrm{F}$ & T2N1M0 & 19 & $7,17,18,20$ \\
\hline UM-SCC-9 & $\mathrm{F}$ & T2NOMO & 19 & $17,18,20$ \\
\hline UM-SCC-10A & M & T3NOMO & 19 & $7,17,18,20,21$ \\
\hline UM-SCC-10B & M & T3N1M0 & 22 & $7,18,20$ \\
\hline UM-SCC-11A & M & T2N2aM0 & 19 & $7,17,18,20$ \\
\hline UM-SCC-11B & M & T2N2aMo & 7 & $7,17,18,20$ \\
\hline UM-SCC-12 & M & T2N1M0 & 19 & 17 \\
\hline UM-SCC-13 & $M$ & T3NOMO & 7 & 17 \\
\hline UM-SCC-14A & $\mathrm{F}$ & T1NOMO & 19 & $7,17,18,20,21$ \\
\hline UM-SCC-14B & $\mathrm{F}$ & T1NOMO & 19 & $7,17,18,20,21$ \\
\hline UM-SCC-14C & $\mathrm{F}$ & T1NOMO & 19 & $7,17,18,20,21$ \\
\hline UM-SCC-15 & M & T4N1M0 & 7 & 7 \\
\hline UM-SCC-16 & $\mathrm{F}$ & T2NOMO & 22 & $7,17,20$ \\
\hline UM-SCC-17A & $\mathrm{F}$ & T1NOMO & 23 & $7,17,20,23,24$ \\
\hline UM-SCC-17as & $\mathrm{F}$ & T1NOMO & 23 & 23 \\
\hline UM-SCC-17B & $\mathrm{F}$ & T1NOMO & 23 & $7,17,20,23,24$ \\
\hline UM-SCC-18 & M & T3N1M0 & 7 & - \\
\hline UM-SCC-19 & M & T2N1M0 & 7 & 7,17 \\
\hline UM-SCC-20 & M & T2N1M0 & 7 & 17,18 \\
\hline UM-SCC-21A & M & T2N1M0 & 25,26 & $7,17,20,26$ \\
\hline UM-SCC-21B & M & T2N1M0 & 18,26 & $7,17,18,20,26$ \\
\hline UM-SCC-22A & $\mathrm{F}$ & T2N1M0 & 7 & $7,17,18$ \\
\hline UM-SCC-22B & $\mathrm{F}$ & T2N1M0 & 19 & $7,17,18$ \\
\hline UM-SCC-23 & $\mathrm{F}$ & T2NOMO & 22 & 7,18 \\
\hline
\end{tabular}




\begin{tabular}{|c|c|c|c|c|}
\hline Cell line & Sex & TNM stage & Reference & Genetics references \\
\hline UM-SCC-24 & M & T1N0M0 & 7 & - \\
\hline UM-SCC-25 & M & T3NOMO & 7 & 17 \\
\hline UM-SCC-26 & M & T3N1M0 & 7 & 17 \\
\hline UM-SCC-27 & M & T1N0M0 & 7 & - \\
\hline UM-SCC-28 & $\mathrm{F}$ & T1NOMO & 7 & 17 \\
\hline UM-SCC-29 & M & T3N2aM0 & 7 & 17 \\
\hline UM-SCC-30 & $\mathrm{F}$ & T3N1M0 & 7 & 17 \\
\hline UM-SCC-31 & $M$ & T3NOMO & 7 & - \\
\hline UM-SCC-32 & $M$ & T3N1M0 & 7 & - \\
\hline UM-SCC-33 & $\mathrm{F}$ & T4N3aMo & 7 & - \\
\hline UM-SCC-34 & M & T3N1M0 & 7 & - \\
\hline UM-SCC-35 & M & T4N1M0 & 19 & 17 \\
\hline UM-SCC-36 & M & T2NOMO & 7 & - \\
\hline UM-SCC-37 & $M$ & T2NOMO & 7 & - \\
\hline UM-SCC-38 & M & T2N2aMo & 19,26 & $7,17,18,26$ \\
\hline UM-SCC-39 & M & T3N3aM0 & 7 & - \\
\hline UM-SCC-40 & M & T3NOMO & 7 & - \\
\hline UM-SCC-41 & M & T2N1M0 & 7 & - \\
\hline UM-SCC-42 & M & T4N3bM0 & 7 & - \\
\hline UM-SCC-43 & M & - & 7 & - \\
\hline UM-SCC-44 & M & T4N2bM0 & 7 & - \\
\hline UM-SCC-45 & $\mathrm{F}$ & T4N2bM0 & 7 & - \\
\hline UM-SCC-46 & $\mathrm{F}$ & - & 7 & 27 \\
\hline UM-SCC-47 & $M$ & T3N1M0 & 7 & 27 \\
\hline UM-SCC-48 & $M$ & T4NOMO & 7 & - \\
\hline UM-SCC-49 & M & T2N1M0 & 7 & 17,18 \\
\hline UM-SCC-50 & $F$ & T4N3bM0 & 7 & - \\
\hline UM-SCC-51 & M & T3N3bM0 & 7 & 17,18 \\
\hline UM-SCC-52 & $\mathrm{F}$ & T3N3cM0 & 7 & - \\
\hline UM-SCC-53 & M & T3N1M0 & 7 & - \\
\hline UM-SCC-54 & M & T3NOMO & 7 & - \\
\hline UM-SCC-55 & $M$ & - & 7 & - \\
\hline UM-SCC-57 & $M$ & - & 7 & - \\
\hline UM-SCC-58 & $\mathrm{F}$ & - & 7 & - \\
\hline UM-SCC-59 & $\mathrm{F}$ & T3N2bM0 & 7 & - \\
\hline UM-SCC-60 & - & - & 7 & - \\
\hline UM-SCC-62 & $M$ & T3N1M0 & 7 & - \\
\hline UM-SCC-63 & M & - & 22 & 7 \\
\hline UM-SCC-65 & M & - & 7 & 17 \\
\hline UM-SCC-66 & M & - & 7 & - \\
\hline UM-SCC-67 & M & - & 7 & - \\
\hline UM-SCC-68A & $M$ & - & 7 & - \\
\hline UM-SCC-68B & M & - & 7 & - \\
\hline UM-SCC-69 & M & T4NOMO & 19 & $7,18,21$ \\
\hline UM-SCC-70 & M & - & 7 & - \\
\hline UM-SCC-71 & $M$ & - & 7 & - \\
\hline UM-SCC-72 & $M$ & - & 7 & - \\
\hline UM-SCC-73A & $M$ & - & 7 & 17 \\
\hline UM-SCC-73B & M & - & 7 & 17 \\
\hline UM-SCC-74A & M & T3NOMO & 7 & - \\
\hline UM-SCC-74B & M & T3NOMO & 7 & - \\
\hline UM-SCC-75 & $\mathrm{F}$ & - & 7 & - \\
\hline UM-SCC-76 & M & - & 7 & - \\
\hline UM-SCC-77 & $\mathrm{F}$ & - & 7 & - \\
\hline UM-SCC-78A & $M$ & - & 7 & - \\
\hline UM-SCC-78B & $M$ & - & 7 & - \\
\hline UM-SCC-79 & M & - & 7 & - \\
\hline UM-SCC-80 & $\mathrm{M}$ & T4N1M0 & 7 & $7,18,21$ \\
\hline UM-SCC-81A & M & T2NOMO & 7 & 24 \\
\hline UM-SCC-81B & M & T2NOMO & 7 & 7,24 \\
\hline UM-SCC-82A & $\mathrm{F}$ & T2NOMO & 7 & $7,17,18,21$ \\
\hline
\end{tabular}


Table A1. (Continued).

\begin{tabular}{|c|c|c|c|c|}
\hline Cell line & Sex & TNM stage & Reference & Genetics references \\
\hline UM-SCC-82B & $\mathrm{F}$ & - & 7 & $17,18,21$ \\
\hline UM-SCC-83A & M & - & 7 & 7,24 \\
\hline UM-SCC-83B & M & - & 7 & 7,24 \\
\hline UM-SCC-84 & M & T2NOMO & 7 & - \\
\hline UM-SCC-85 & M & - & 7 & - \\
\hline UM-SCC-86 & $\mathrm{F}$ & - & 7 & 24 \\
\hline UM-SCC-87 & M & T3NOMO & 7 & 7,24 \\
\hline UM-SCC-88 & $\mathrm{F}$ & T3N1M1 & 7 & - \\
\hline UM-SCC-89 & M & T3NOMO & 7 & 24 \\
\hline UM-SCC-90 & M & T4N3M0 & 7 & 7,24 \\
\hline UM-SCC-91 & M & T4NOMO & 7 & 24 \\
\hline UM-SCC-92 & $\mathrm{F}$ & T2NOMO & 7 & - \\
\hline UM-SCC-93 & $\mathrm{F}$ & T4NOMO & 7 & 7,24 \\
\hline UM-SCC-94 & M & T4N2aMo & 7 & 24 \\
\hline UM-SCC-95 & M & T4N1M0 & 7 & - \\
\hline UM-SCC-96 & $\mathrm{F}$ & T3N3M0 & 7 & - \\
\hline UM-SCC-97 & $\mathrm{F}$ & T1NOMO & 7 & - \\
\hline UM-SCC-98 & M & T4NOMO & 7 & - \\
\hline UM-SCC-99 & M & T3NOMO & 7 & - \\
\hline UM-SCC-100 & $\mathrm{F}$ & T4N3M0 & 7 & - \\
\hline UM-SCC-101A & $\mathrm{F}$ & T2N3M0 & 7 & 7 \\
\hline UM-SCC-101B & $\mathrm{F}$ & T2N3M0 & 7 & - \\
\hline SCC $-4^{*}$ & $M$ & T3NOMO & 28 & - \\
\hline SCC-9* & $M$ & T2N1 & 28 & - \\
\hline SCC-12 & M & - & 28 & - \\
\hline SCC-13 & $\mathrm{F}$ & - & 28 & - \\
\hline SCC-15* & $M$ & T4N1M0 & 28 & - \\
\hline SCC-25* & M & T2N1 & 28,29 & 7 \\
\hline SCC-35 & - & T4NO & 29,30 & 7 \\
\hline SCC-49 & - & T2NO & 30 & - \\
\hline SCC-61 & - & T4N2b & 29,30 & 7 \\
\hline SCC-66 & - & T4NO & 30 & - \\
\hline SCC-68 & M & T4N10M0 & 7 & - \\
\hline SCC-71 & - & $\mathrm{T} 4 \mathrm{~N} 1$ & 30 & - \\
\hline SCC-73 & - & T4N0 & 30 & - \\
\hline SCC-74 & $\mathrm{F}$ & T4NOMO & 7 & - \\
\hline SCC-76 & - & T4NO & 30 & - \\
\hline SCC-182 & $M$ & T3NOMO & 7 & - \\
\hline SCC-200 & $M$ & T2N2MO & 7 & - \\
\hline SCC-203 & $M$ & T2N2MO & 7 & - \\
\hline SCC-210 & M & T3NOMO & 7 & - \\
\hline SCC-213 & M & T4NOMO & 7 & - \\
\hline SCC-220 & $\mathrm{M}$ & T4N1M0 & 7 & - \\
\hline JSQ-3 & - & T3NO & 29,31 & 7 \\
\hline JSQ-13 & - & - & 32 & - \\
\hline SQ-9G & - & T3N1 & 30 & 7 \\
\hline SQ-20B & - & T2NO & 29,30 & 7 \\
\hline SQ-29 & - & T3N1 & 30 & - \\
\hline SQ-31 & - & T2NO & 29,30 & 7 \\
\hline SQ-38 & - & T3NO & 30 & 7 \\
\hline SQ-39 & - & T3N2a & 30 & - \\
\hline$S Q-43$ & - & T1NO & 30 & - \\
\hline SQ-50 & - & T4N2 & 7 & - \\
\hline HN-SCC-3 & - & T3N3bM0 & 31 & - \\
\hline HN-SCC-28 & - & - & 31 & - \\
\hline HN-SCC-29 & - & - & 32 & - \\
\hline HN-SCC-42 & - & - & 32 & - \\
\hline HN-SCC-58 & - & T4N1M0 & 31 & - \\
\hline HN-SCC-68 & - & - & 32 & - \\
\hline HN-SCC-80 & - & - & 32 & - \\
\hline HN-SCC-104 & - & T3N3aM0 & 31 & - \\
\hline
\end{tabular}

174 Head and Neck Squamous Cell Carcinoma Cancer Cell Lines 
Table A1. (Continued).

\begin{tabular}{|c|c|c|c|c|}
\hline Cell line & Sex & TNM stage & Reference & Genetics references \\
\hline HN-SCC-109A & - & - & 32 & - \\
\hline HN-SCC-131 & - & - & 31 & - \\
\hline HN-SCC-135 & - & T1N1MO & 29 & 7 \\
\hline HN-SCC-151 & - & T3NOMO & 29 & 7 \\
\hline HN-SCC-167 & - & T3NOMO & 29 & 7 \\
\hline HN-SCC-294 & - & T2NOMO & 29 & 7 \\
\hline $\mathrm{PCl}-1$ & $M$ & - & 33,34 & 7,33 \\
\hline $\mathrm{PCl}-2$ & M & T3NOMO & 33 & 7,33 \\
\hline $\mathrm{PCl}-3$ & - & T3NOMO & 33 & 7,33 \\
\hline $\mathrm{PCl}-4 \mathrm{~A}$ & M & T3NOMO & 33,34 & 7,33 \\
\hline $\mathrm{PCl}-4 \mathrm{~B}$ & M & T3NOMO & 33,34 & 7,33 \\
\hline $\mathrm{PCl}-5$ & M & T3N1M0 & 33 & 7,33 \\
\hline $\mathrm{PCl}-6 \mathrm{~A}$ & $M$ & T3N3M0 & 33,34 & 7,33 \\
\hline $\mathrm{PCl}-6 \mathrm{~B}$ & $M$ & T3N3M0 & 33,34 & 7,33 \\
\hline $\mathrm{PCl}-7$ & $M$ & T4N2M0 & 33 & 7,33 \\
\hline PCl-8 & M & T3NOMO & 33 & 33 \\
\hline PCl-9A & & T4N3M0 & 33 & 7,33 \\
\hline $\mathrm{PCl}-9 \mathrm{~B}$ & M & T4N3M0 & 33 & 7,33 \\
\hline $\mathrm{PCl}-10$ & $M$ & T3N1M0 & 33 & 7,33 \\
\hline $\mathrm{PCl}-11$ & $M$ & T4N1M0 & 33,34 & 7,33 \\
\hline $\mathrm{PCl}-12$ & M & - & 33 & 7,33 \\
\hline $\mathrm{PCl}-13$ & $M$ & T4N1M0 & 33,34 & 7,33 \\
\hline $\mathrm{PCl}-14$ & $M$ & - & 33 & - \\
\hline $\mathrm{PCl}-15 \mathrm{~A}$ & $M$ & T2N1M0 & 33,34 & - \\
\hline $\mathrm{PCl}-15 \mathrm{~B}$ & M & T2N1M0 & 33,34 & - \\
\hline $\mathrm{PCl}-16$ & $M$ & T2N1M0 & 33 & - \\
\hline $\mathrm{PCl}-17$ & $\mathrm{~F}$ & T2NOMO & 33 & - \\
\hline PCl-18 & $M$ & - & 33 & - \\
\hline PCl-19 & $M$ & T3NOMO & 7 & - \\
\hline $\mathrm{PCl}-20$ & $M$ & - & 7 & - \\
\hline PCl-21 & $M$ & T3N2M0 & 7 & - \\
\hline $\mathrm{PCl}-22 \mathrm{~A}$ & $M$ & T4N1M0 & 34,35 & - \\
\hline $\mathrm{PCl}-22 \mathrm{~B}$ & $M$ & T4N1M0 & 34,35 & - \\
\hline $\mathrm{PCl}-23$ & $\mathrm{~F}$ & T2NOMO & 36 & - \\
\hline $\mathrm{PCl}-24$ & $M$ & T2NOMO & 33 & - \\
\hline $\mathrm{PCl}-25$ & $M$ & T4N1M0 & 34,35 & - \\
\hline $\mathrm{PCl}-26$ & $M$ & T3NOMO & 34 & - \\
\hline $\mathrm{PCl}-27$ & $M$ & T4NOMO & 7 & - \\
\hline $\mathrm{PCl}-28$ & $M$ & T3N2M0 & 34,35 & - \\
\hline $\mathrm{PCl}-29$ & $\mathrm{~F}$ & T4NOMO & 7 & - \\
\hline $\mathrm{PCl}-30$ & $M$ & T3N1M0 & 34,36 & - \\
\hline PCl-31 & $M$ & T3NOMO & 34 & - \\
\hline PCl-32 & $M$ & T4NOMO & 37 & - \\
\hline PCl-33 & $M$ & - & 34 & - \\
\hline PCl-34 & $M$ & T4N2M0 & 34 & - \\
\hline PCl-35 & M & T3N1M0 & 7 & - \\
\hline PCl-36 & $\mathrm{F}$ & T2NOMO & 34 & - \\
\hline PCI-37A & $M$ & T3N2MO & 34 & - \\
\hline $\mathrm{PCl}-37 \mathrm{~B}$ & $M$ & T3N2M0 & 34 & - \\
\hline PCl-38 & $M$ & T3N1M0 & 34,36 & - \\
\hline PCl-39 & M & T2NOMO & 34 & - \\
\hline $\mathrm{PCl}-40$ & $M$ & T4N2M0 & 7 & - \\
\hline $\mathrm{PCl}-41$ & $\mathrm{~F}$ & T2NOMO & 7 & - \\
\hline $\mathrm{PCl}-42$ & $M$ & T4N2M0 & 7 & - \\
\hline $\mathrm{PCl}-43$ & M & T1NOMO & 7 & - \\
\hline $\mathrm{PCl}-44$ & $\mathrm{M}$ & T4NOMO & 7 & - \\
\hline $\mathrm{PCl}-45$ & $\mathrm{M}$ & T4N3M0 & 7 & - \\
\hline $\mathrm{PCl}-46$ & $M$ & T2N2MO & 7 & - \\
\hline $\mathrm{PCl}-47$ & $\mathrm{~F}$ & T3NOMO & 7 & - \\
\hline PCl-50 & $M$ & T2NOMO & 38 & - \\
\hline PCl-51 & $\mathrm{M}$ & T1N2M0 & 39 & - \\
\hline
\end{tabular}




\begin{tabular}{|c|c|c|c|c|}
\hline \multicolumn{5}{|c|}{ Table A1. (Continued). } \\
\hline Cell line & Sex & TNM stage & Reference & Genetics references \\
\hline PCl-52 & M & T1N2M0 & 40 & - \\
\hline $\mathrm{PCl}-100$ & M & T3N1M0 & 7 & - \\
\hline PCl-101 & M & T4N2M0 & 7 & - \\
\hline PCl-102 & M & T2NOMO & 7 & - \\
\hline $\mathrm{PCl}-103$ & M & T3NOMO & 7 & - \\
\hline PCl-104 & M & T4N3M0 & 7 & - \\
\hline PCl-105 & M & T3NOMO & 7 & - \\
\hline $\mathrm{PCl}-106$ & $\mathrm{~F}$ & T4N2M0 & 7 & - \\
\hline UT-SCC-1A & $\mathrm{F}$ & T2N1M0 & 19,41 & 7 \\
\hline UT-SCC-1B & $\mathrm{F}$ & T4N1M0 & 42 & 7 \\
\hline UT-SCC-2 & M & T4N1M0 & 19,41 & 7 \\
\hline UT-SCC-4 & $\mathrm{F}$ & T4NOMO & 41 & 7 \\
\hline UT-SCC-5 & M & T1N1M0 & 42 & 7 \\
\hline UT-SCC-6A & $\mathrm{F}$ & T2N1M0 & 42 & 7,43 \\
\hline UT-SCC-6B & $\mathrm{F}$ & T2N1M0 & 42 & 7 \\
\hline UT-SCC-7 & $\mathrm{M}$ & T1NOMO & 41 & 7 \\
\hline UT-SCC-8 & $\mathrm{M}$ & T2NOMO & 42 & 7,43 \\
\hline UT-SCC-9 & $\mathrm{M}$ & T2NOMO & 42 & 7,43 \\
\hline UT-SCC-10 & $\mathrm{M}$ & T1NOMO & 42 & 7,43 \\
\hline UT-SCC-11 & M & T1N0M0 & 41 & 7 \\
\hline UT-SCC-12A & $\mathrm{F}$ & T2NOMO & 41 & 7 \\
\hline UT-SCC-12B & $\mathrm{F}$ & T2NOMO & 42 & 7 \\
\hline UT-SCC-13 & M & T3NOMO & 42 & 7 \\
\hline UT-SCC-14 & M & T3N1M0 & 42 & 7 \\
\hline UT-SCC-15 & M & T1NOMO & 7 & 7 \\
\hline UT-SCC-16A & $\mathrm{F}$ & T3NOMO & 41 & 7,43 \\
\hline UT-SCC-16B & $\mathrm{F}$ & T3NOMO & 42 & 7 \\
\hline UT-SCC-17 & M & T2NOMO & 7 & 7 \\
\hline UT-SCC-18 & M & T3N1M0 & 42 & 7,43 \\
\hline UT-SCC-19A & M & T4NOMO & 44 & 7,43 \\
\hline UT-SCC-19B & M & T4NOMO & 44 & 7 \\
\hline UT-SCC-20A & $\mathrm{F}$ & T1N0M0 & 42 & 7 \\
\hline UT-SCC-20B & $\mathrm{F}$ & - & 42 & 7 \\
\hline UT-SCC-21 & M & T3NOMO & 7 & 7 \\
\hline UT-SCC-22 & M & T1NOMO & 44 & 7 \\
\hline UT-SCC-23 & M & T3NOMO & 7 & 7 \\
\hline UT-SCC-24A & M & T2NOMO & 42 & 7 \\
\hline UT-SCC-24B & $\mathrm{M}$ & T2NOMO & 42 & 7,43 \\
\hline UT-SCC-25 & $\mathrm{M}$ & T2NOMO & 42 & 7 \\
\hline UT-SCC-26A & $\mathrm{M}$ & T1N2M0 & 42 & 7 \\
\hline UT-SCC-26B & M & T1N2M0 & 42 & 7 \\
\hline UT-SCC-27 & M & T2NOMO & 7 & 7 \\
\hline UT-SCC-28 & $\mathrm{F}$ & T2NOMO & 7 & 7 \\
\hline UT-SCC-29 & M & T2NOMO & 42,44 & 7,43 \\
\hline UT-SCC-30 & $\mathrm{F}$ & T3N1M0 & 7 & 7 \\
\hline UT-SCC-31 & $M$ & T3N2bMO & 7 & 7 \\
\hline UT-SCC-32 & $\mathrm{M}$ & T3NOMO & 7 & 7 \\
\hline UT-SCC-33 & $\mathrm{F}$ & T2NOMO & 7 & 7 \\
\hline UT-SCC-34 & M & T4NOMO & 7 & 7 \\
\hline UT-SCC-35 & M & T2NOMO & 7 & 7 \\
\hline UT-SCC-36 & M & T4N1M0 & 7 & 7 \\
\hline UT-SCC-37 & $\mathrm{F}$ & T2NOMO & 7 & - \\
\hline UT-SCC-38 & M & T2NOMO & 7 & - \\
\hline UT-SCC-39 & M & T2NOMO & 7 & - \\
\hline UT-SCC-40 & M & T3NOMO & 7 & - \\
\hline UT-SCC-41 & M & T3NOMO & 7 & - \\
\hline UT-SCC-42A & M & T4N3M0 & 7 & - \\
\hline UT-SCC-42B & M & T4N3M0 & 7 & - \\
\hline UT-SCC-43A & $\mathrm{F}$ & T4N1M0 & 7 & - \\
\hline UT-SCC-43B & $\mathrm{F}$ & T4N1M0 & 7 & - \\
\hline UT-SCC-44 & $\mathrm{F}$ & T4N2bM0 & 7 & - \\
\hline
\end{tabular}


Table A1. (Continued).

\begin{tabular}{|c|c|c|c|c|}
\hline Cell line & Sex & TNM stage & Reference & Genetics references \\
\hline UT-SCC-45 & M & T3N1M0 & 7 & - \\
\hline UT-SCC-46A & M & T1NOMO & 7 & - \\
\hline UT-SCC-46B & M & T1N0M0 & 7 & - \\
\hline UT-SCC-47 & M & T2NOMO & 7 & - \\
\hline UT-SCC-48 & M & T3NOMO & 7 & - \\
\hline UT-SCC-49 & M & T2NOMO & 7 & - \\
\hline UT-SCC-50 & M & T2No & 7 & - \\
\hline UT-SCC-51 & $M$ & T2NOMO & 7 & - \\
\hline UT-SCC-52 & M & T2N1M0 & 7 & - \\
\hline UT-SCC-53 & $M$ & T4N2cMo & 7 & - \\
\hline UT-SCC-54A & $\mathrm{F}$ & T2NOMO & 7 & - \\
\hline UT-SCC-54B & $\mathrm{F}$ & T2NOMO & 7 & - \\
\hline UT-SCC-55 & M & T4N1M0 & 7 & - \\
\hline EV-SCC-1 & $\mathrm{M}$ & T2NOMO & 22 & - \\
\hline EV-SCC-2 & $\mathrm{M}$ & $\mathrm{T} 2 \mathrm{~N} 2 \mathrm{aMO}$ & 7 & - \\
\hline EV-SCC-3 & $M$ & T2N2bM0 & 22 & - \\
\hline EV-SCC-4 & $\mathrm{M}$ & T3N1M0 & 22 & - \\
\hline EV-SCC-7 & $\mathrm{M}$ & T4NOMO & 7 & - \\
\hline EV-SCC-10M & M & T4N1M0 & 7 & - \\
\hline EV-SCC-14M & M & T2N2bM0 & 7 & - \\
\hline EV-SCC-17P & M & T4NOMO & 7 & - \\
\hline EV-SCC-17M & $\mathrm{M}$ & T4NOMO & 7 & - \\
\hline EV-SCC-18 & M & T3N1M0 & 7 & - \\
\hline EV-SCC-19P & $\mathrm{M}$ & T3N1M0 & 7 & - \\
\hline EV-SCC-19M & $\mathrm{M}$ & T3N1M0 & 7 & - \\
\hline HFH-SCC-3 & $M$ & T1N0M0 & 21 & 21 \\
\hline HFH-SCC-4 & $M$ & T4NOMO & 21 & 21 \\
\hline HFH-SCC-6 & M & T2N1M0 & 21 & 21,45 \\
\hline HFH-SCC-8 & M & $\mathrm{T} 1 \mathrm{~N} 1 \mathrm{M} 0$ & 21 & 46 \\
\hline HFH-SCC-11 & M & T3NOMO & 21 & 21 \\
\hline HFH-SCC-12 & $\mathrm{M}$ & T2N2bM0 & 21 & 21 \\
\hline HFH-SCC-15 & $\mathrm{F}$ & - & 21 & 21 \\
\hline HFH-SCC-16 & $M$ & T2N2M0 & 21 & 21 \\
\hline HFH-SCC-17 & - & NS & 18 & 18 \\
\hline HFH-SCC-19 & $M$ & T1N2M0 & 21 & 21 \\
\hline HFH-SCC-20 & $\mathrm{M}$ & T4N3M0 & 21 & 21 \\
\hline HFH-SCC-28 & $\mathrm{M}$ & T2NOMO & 21 & 21 \\
\hline HFH-SCC-29 & $\mathrm{F}$ & - & 21 & 21 \\
\hline HFH-SCC-33 & $M$ & T4N2M0 & 21 & 21 \\
\hline HFH-SCC-42 & $M$ & T2NOMO & 21 & 21 \\
\hline AMC-HN-1 & $\mathrm{M}$ & T1NOMO & 47 & 47 \\
\hline AMC-HN-2 & $\mathrm{M}$ & T4N2M0 & 47 & 47 \\
\hline AMC-HN-3 & $\mathrm{M}$ & T3N1M0 & 47 & 47 \\
\hline AMC-HN-4 & $\mathrm{F}$ & T4NOMO & 47 & 47 \\
\hline AMC-HN-5 & $\mathrm{M}$ & T3NOMO & 47 & 47 \\
\hline AMC-HN-6 & M & T4N2MO & 47 & 47 \\
\hline AMC-HN-7 & $\mathrm{M}$ & T4N2MO & 47 & 47 \\
\hline AMC-HN-8 & $\mathrm{M}$ & T3N2MO & 47 & 47 \\
\hline AMC-HN-9 & $\mathrm{F}$ & T4N2MO & 47 & 47 \\
\hline UD-SCC-1 & $M$ & T3N2bM0 & 48 & 48 \\
\hline UD-SCC-2 & $\mathrm{M}$ & T1N2M0 & 48 & 48 \\
\hline UD-SCC-3 & $\mathrm{M}$ & T2N2cMo & 48 & 48 \\
\hline UD-SCC-4 & $\mathrm{M}$ & T3N1MO & 48 & 48 \\
\hline UD-SCC-5 & M & T1N1M0 & 7 & 48 \\
\hline UD-SCC-6 & M & T2NOMO & 7 & 48 \\
\hline HNSCCUM-01T & M & T2N2cM0 & 7 & - \\
\hline HNSCCUM-02T & M & T3N3bM0 & 7 & - \\
\hline HNSCCUM-03T & $\mathrm{M}$ & T3N2bMO & 7 & - \\
\hline HNSCCUM-04N & $\mathrm{M}$ & T1N1M0 & 7 & - \\
\hline HNSCCUM-05N & $\mathrm{M}$ & T1N2bM0 & 7 & - \\
\hline HNSCCUM-06N & $\mathrm{M}$ & $\mathrm{T} 2 \mathrm{~N} 2 \mathrm{CMO}$ & 7 & - \\
\hline
\end{tabular}




\begin{tabular}{|c|c|c|c|c|}
\hline Cell line & Sex & TNM stage & Reference & Genetics references \\
\hline HNSCCUM-07N & $M$ & T2N2bM0 & 7 & - \\
\hline TU-138 & M & T3NOMO & 49 & - \\
\hline TU-158 LN & M & T2N2aMo & 49 & - \\
\hline TU-159 & M & T3NOMO & 49 & - \\
\hline TU-167 & $\mathrm{F}$ & T4N2bM0 & 49 & - \\
\hline TU-177 & M & T3NOMO & 49 & - \\
\hline TU-182 & $\mathrm{F}$ & T3N2bM0 & 49 & - \\
\hline TU-202 & - & - & 7 & - \\
\hline TU-212 & M & T2N2cMO & 49 & - \\
\hline TU-212 LN & M & T2N2cMO & 49 & - \\
\hline TU-358B & - & - & 7 & - \\
\hline TU-686 & - & - & 7 & - \\
\hline CAL 33 & - & - & 50 & 50 \\
\hline CAL $27^{*}$ & $M$ & - & 50 & 50 \\
\hline TR126 & $\mathrm{F}$ & - & 51 & - \\
\hline TR131 & M & - & 51 & - \\
\hline TR138 & M & - & 51 & - \\
\hline TR146 & $\mathrm{F}$ & - & 51 & - \\
\hline MDA-183 & M & T3NOMO & 52 & 7,52 \\
\hline MDA-1483 & M & T2N1M0 & 52 & 7,52 \\
\hline $584 \mathrm{~A} 2$ & - & - & 53 & 53 \\
\hline MDA-886LN & M & T3N3a & 54 & - \\
\hline T1/CUHK & - & - & 55 & 55 \\
\hline T2/CUHK & - & - & 55 & 55 \\
\hline MDA-686Ln & - & - & 56 & - \\
\hline HTB43 & - & - & 57 & - \\
\hline UPCI:SCC003 & $\mathrm{F}$ & T1N0 & 58,59 & $58-60$ \\
\hline UPCI:SCC016 & $\mathrm{F}$ & T1N0 & 58,59 & 58,59 \\
\hline UPCI:SCC029 & M & T4N2 & 58,59 & 58,59 \\
\hline UPCI:SCC030 & M & T4N2B & 58,59 & 58,59 \\
\hline UPCI:SCC032 & M & T2N2B & $58,59,61$ & $58,59,61$ \\
\hline UPCI:SCC036 & $M$ & T3N1 & $58,59,61$ & $58,59,61$ \\
\hline UPCI:SCC040 & M & T2N2 & 58,59 & $58,59,62-67$ \\
\hline UPCI:SCC056 & M & T3N2B & $58,59,61$ & $58,59,61,63,65$ \\
\hline UPCI:SCC070 & $\mathrm{F}$ & T3N1 & $58,59,61$ & $58,59,61$ \\
\hline UPCI:SCC072 & $\mathrm{F}$ & T3N2B & $58,59,61$ & $58,59,61$ \\
\hline UPCI:SCC074 & $\mathrm{F}$ & T4N1 & 59,61 & 59,61 \\
\hline UPCI:SCC075 & $M$ & T3N2B & $58,59,61$ & $58,59,61$ \\
\hline UPCI:SCC077 & $\mathrm{M}$ & T2N2 & $58,59,61$ & $58,59,61$ \\
\hline UPCI:SCC078 & M & T2NO & $58,59,61$ & $58,59,61,68$ \\
\hline UPCI:SCC080 & M & T1N0 & 58,59 & 58,59 \\
\hline UPCI:SCC081 & $\mathrm{F}$ & T4NO & 59,61 & 59,61 \\
\hline UPCI:SCC084 & $M$ & T2N2B & $58,59,61$ & $58,59,61$ \\
\hline UPCI:SCC089 & M & T4N2B & 59,61 & 59,61 \\
\hline UPCI:SCC090 & $\mathrm{M}$ & T2NO & $59,62,69$ & $59,62,69$ \\
\hline UPCI:SCC099 & M & T1No & 58,59 & 58,59 \\
\hline UPCI:SCC103 & $\mathrm{F}$ & T1No & $58,59,61$ & $58,59,61,64,66,68$ \\
\hline UPCI:SCC104 & M & T4NX & $58,59,61$ & $58,59,61$ \\
\hline UPCI:SCC105 & M & T2NO & $58,59,61$ & $58,59,61$ \\
\hline UPCI:SCC111 & $\mathrm{F}$ & T1N1 & $58,59,61$ & $58,59,61$ \\
\hline UPCI:SCC114 & M & T2NO & $58,59,61$ & $58,59,61,63,65,70$ \\
\hline UPCI:SCC116 & M & T2NO & $58,59,61$ & $58,59,61$ \\
\hline UPCI:SCC122 & M & T1N1 & $58,59,61$ & $58,59,61$ \\
\hline UPCI:SCC125 & $\mathrm{F}$ & T4N2B & $58,59,61$ & $58,59,61$ \\
\hline UPCI:SCC131 & M & T2N2 & $58,59,61$ & $58-61,67$ \\
\hline UPCI:SCC136 & $\mathrm{F}$ & T3N2 & $58,59,61$ & $58,59,61$ \\
\hline UPCI:SCC142 & M & T4NX & $58,59,61$ & $58,59,61$ \\
\hline UPCI:SCC154 & M & T4N2 & 58,59 & 58,59 \\
\hline UPCI:SCC172 & M & - & 58,59 & $58-60$ \\
\hline UPCI:SCC182 & $\mathrm{M}$ & T2N1 & 58,59 & 58,59 \\
\hline JHU-11-SCC & M & T3NO & $71-73$ & - \\
\hline
\end{tabular}

178 Head and Neck Squamous Cell Carcinoma Cancer Cell Lines 
Table A1. (Continued).

\begin{tabular}{lclcc}
\hline Cell line & Sex & TNM stage & Reference & Genetics references \\
\hline JHU-12-SCC & F & T1N2b & 71 & - \\
JHU-2O-SCC & M & T2N2b & $72-74$ & - \\
JHU-22-SCC & M & T3N2b & $72-74$ & - \\
JHU-29-SCC & $M$ & T4NO & 71 & - \\
\hline
\end{tabular}

*HNSCC cell lines available from the American Type Culture Collection (ATCC).

Table A2. TP53 gene mutations.

\begin{tabular}{|c|c|c|c|}
\hline Cell line & Mutation & Protein detection IB/IHC* & References \\
\hline Ca9-22 & R248W & + & - \\
\hline FS-1 & $\mathrm{R} 273 \mathrm{H}$ & + & - \\
\hline HSC-3 & aa305-306 INSERTION & + & - \\
\hline HSC-4 & $\mathrm{R} 248 \mathrm{Q}$ & + & - \\
\hline HSQ-89 & G266E & + & - \\
\hline K562 & wt & - & - \\
\hline Kuma-3 & C176F & + & - \\
\hline MO24 & wt & - & 33 \\
\hline $\mathrm{PCl}-13$ & E286K & & $33,37,75$ \\
\hline $\mathrm{PCl}-30$ & wt & & $33,37,75$ \\
\hline $\mathrm{PCl}-4 \mathrm{~B}$ & & & $33,37,75$ \\
\hline SCC-4 & T150L & + & 33 \\
\hline SCC-9 & del275-285 & - & 33 \\
\hline TE-11 & R110L & + & - \\
\hline UD-SCC-1 & Skip exon 3 & $-1-$ & 48,76 \\
\hline UD-SCC-2 & & $-1-$ & 48,76 \\
\hline UD-SCC-3 & & $-1-$ & 48,76 \\
\hline UD-SCC-5 & $\mathrm{H} 179 \mathrm{Y}$ & $+/+$ & 48,76 \\
\hline UD-SCC-6 & Y220C & $+/+$ & 48,76 \\
\hline UD-SCC-7A/B/C & $\mathrm{R} 248 \mathrm{~L}$ & $+/+$ & 48,76 \\
\hline UD-SCC-8 & $\mathrm{T} 155 \mathrm{~N}$ & $+/+$ & 48,76 \\
\hline UM-SCC-1 & & & 16,77 \\
\hline UM-SCC-5 & V157F & & 16,77 \\
\hline UM-SCC-6 & & & 16,77 \\
\hline UM-SCC-10A/B & G245C & $+/+$ & $16,76,77$ \\
\hline UM-SCC-11B & C242S & $+/+$ & $16,76,77$ \\
\hline UM-SCC-12 & Q110 stop & & 16,77 \\
\hline UM-SCC-13 & Y163C & & 16,77 \\
\hline UM-SCC-14A/B/C & R280S & $+/+$ & $16,76,77$ \\
\hline UM-SCC-17A/B & wt & $-1-$ & $16,76,77$ \\
\hline UM-SCC-22A/B & Y220C & $+/+$ & $16,76,77$ \\
\hline UM-SCC-23 & $\mathrm{C} 176 \mathrm{~F}$ & & 16,77 \\
\hline UM-SCC-25 & wt & & 16,77 \\
\hline UM-SCC-36 & $\mathrm{R} 158 \mathrm{P}$ & & 16,77 \\
\hline UM-SCC-46 & P278A & & 16,77 \\
\hline UM-SCC-47 & wt & & 16,77 \\
\hline UM-SCC-54 & & & 16,77 \\
\hline UM-SCC-57 & R273L & & 16,77 \\
\hline UM-SCC-68 & R248W & & 16,77 \\
\hline UM-SCC-72 & wt & & 16,77 \\
\hline UM-SCC-74A & wt & & 16,77 \\
\hline UM-SCC-74B & wt & & 16,77 \\
\hline UM-SCC-81A & wt & & 16,77 \\
\hline UM-SCC-81B & H193R & & 16,77 \\
\hline UPCI:SCC-16 & R282W & & 78 \\
\hline UPCI:SCC-29B & R280T & & 78 \\
\hline UPCI:SCC-32 & Del2bp & & 78 \\
\hline UPCI:SCC-36 & I195F & & 78 \\
\hline UPCI:SCC-70 & $\mathrm{R} 248 \mathrm{Q}$ & & 78 \\
\hline UPCI:SCC-72 & $\mathrm{H} 179 \mathrm{~N}$ & & 78 \\
\hline
\end{tabular}




\begin{tabular}{|c|c|c|c|c|c|}
\hline \multicolumn{6}{|c|}{ Table A2. (Continued). } \\
\hline Cell line & \multicolumn{2}{|c|}{ Mutation } & \multicolumn{2}{|c|}{ Protein detection $\mathrm{IB} / \mathrm{IHC}^{*}$} & References \\
\hline UPCI:SCC-77 & \multicolumn{2}{|c|}{ Del1bp } & & & 78 \\
\hline UPCI:SCC-84 & \multicolumn{2}{|c|}{ Del1bp } & & & 78 \\
\hline UPCI:SCC-99 & \multicolumn{2}{|c|}{ P177R } & & & 78 \\
\hline UPCI:SCC-103 & \multicolumn{2}{|c|}{ R306X } & & & 78 \\
\hline UPCI:SCC-105 & \multicolumn{2}{|c|}{$\mathrm{T} 155 \mathrm{P}$} & & & 78 \\
\hline UPCI:SCC-111 & \multicolumn{2}{|c|}{$\mathrm{H} 189 \mathrm{Y}$} & & & 78 \\
\hline UPCI:SCC-114 & \multicolumn{2}{|c|}{ R248Q } & & & 78 \\
\hline UPCI:SCC-116 & \multicolumn{2}{|c|}{$\mathrm{R} 175 \mathrm{H}$} & & & 78 \\
\hline UPCI:SCC-122 & \multicolumn{2}{|c|}{$\mathrm{R} 273 \mathrm{H}$} & & & 78 \\
\hline UPCI:SCC-125 & \multicolumn{2}{|c|}{$\mathrm{P} 151 \mathrm{H}$} & & & 78 \\
\hline UPCI:SCC-136 & \multicolumn{2}{|c|}{ E224X } & & & 78 \\
\hline UPCI:SCC-172 & \multicolumn{2}{|c|}{ T155P } & & & 78 \\
\hline UPCI:SCC-182 & \multicolumn{2}{|c|}{ E294X } & & & 78 \\
\hline UT-MUC-1 & & & & & $19,79,80$ \\
\hline UT-SCC-1A & & & & & $19,79,80$ \\
\hline UT-SCC-2 & & & & & $19,79,80$ \\
\hline UT-SCC-4 & & & & & $19,79,80$ \\
\hline UT-SCC-5 & & & & & $19,79,80$ \\
\hline UT-SCC-6A/B & & & & & $19,79,80$ \\
\hline UT-SCC-7 & G266 & & & $+/+$ & $19,79,80$ \\
\hline UT-SCC-8 & & & & & $19,79,80$ \\
\hline UT-SCC-9 & & & & $-1-$ & $19,79,80$ \\
\hline UT-SCC-14 & Skip & 8 insertion intron 8 & & $+/+$ & $19,79,80$ \\
\hline UT-SCC-15 & N77 & & & $-1-$ & $19,79,80$ \\
\hline UT-SCC-15 & & & & & $19,79,80$ \\
\hline UT-SCC-16A & & & & & $19,79,80$ \\
\hline UT-SCC-20B & & & & & $19,79,80$ \\
\hline UT-SCC-22 & $\mathrm{C} 238$ & & & $+/+$ & $19,79,80$ \\
\hline UT-SCC-23 & & & & $-1-$ & $19,79,80$ \\
\hline UT-SCC-24A/B & NT 77 & & & $-1-$ & $19,79,80$ \\
\hline UT-SCC-33 & R282 & & & $+/+$ & $19,79,80$ \\
\hline UT-SCC-34 & & & & $-1-$ & $19,79,80$ \\
\hline UT-SCC-50 & Skip & & & $-1-$ & $19,79,80$ \\
\hline Abbreviations: IB, & noblot; IHC, immun & chemistry. & & & \\
\hline Oral cavity & Oronharynx & Hyponharynx & arynx & Paranasal/nasal sinus & Facial skin \\
\hline Hen 3 (Hel a?) & Diveris & 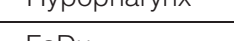 & the & 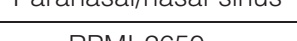 & 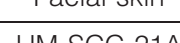 \\
\hline $\begin{array}{l}\text { Hep3 (HeLa?) } \\
\text { KB (Hel }\end{array}$ & UM-SCC-4 & $\begin{array}{l}\text { FaDu } \\
\text { UM-SCC-15 }\end{array}$ & Hep2 (HeLa?) & RPMI 2650 & $\begin{array}{l}\text { UM-SCC-21A } \\
\text { UM-SCC-21B }\end{array}$ \\
\hline $\begin{array}{l}\text { KB (HeLa?) } \\
\text { SW579 }\end{array}$ & $\begin{array}{l}\text { UM-SCC-6 } \\
\text { UM-SCC-18 }\end{array}$ & $\begin{array}{l}\text { UM-SCC-15 } \\
\text { UM-SCC-22A }\end{array}$ & $\begin{array}{l}\text { HLac78 } \\
\text { HLac79 }\end{array}$ & $\begin{array}{c}\text { MC } \\
\text { UM-SCC-3 }\end{array}$ & $\begin{array}{l}\text { UM-SCC-21B } \\
\text { UM-SCC-63 }\end{array}$ \\
\hline A-253 & UM-SCC-19 & UM-SCC-22B & $\mathrm{HN}-2$ & UM-SCC-33 & SCC-12 \\
\hline T3M-1 & UM-SCC-26 & UM-SCC-30 & $\mathrm{HN}-4$ & UM-SCC-85 & SCC-13 \\
\hline $\mathrm{HN}-1$ & UM-SCC-31 & UM-SCC-37 & HN-8 & UT-SCC-53 & $\mathrm{PCl}-20$ \\
\hline $\mathrm{HN}-3$ & UM-SCC-34 & UM-SCC-39 & HN-9 & AMC-HN-5 & UT-SCC-7 \\
\hline HN-5 & UM-SCC-35 & UM-SCC-42 & $\mathrm{HN}-10$ & & UT-SCC-12A \\
\hline $\mathrm{HN}-6$ & UM-SCC-38 & UM-SCC-53 & UM-SCC-5 & & UT-SCC-12B \\
\hline $\mathrm{HN}-6 \mathrm{Rr}$ & UM-SCC-50 & UM-SCC-60 & UM-SCC-10A & & \\
\hline $\mathrm{HN}-6 \mathrm{Rr}$ & UM-SCC-62 & UM-SCC-80 & UM-SCC-10B & & \\
\hline $\mathrm{HN}-6 \mathrm{Rr}$ & UM-SCC-65 & UM-SCC-88 & UM-SCC-11A & & \\
\hline $\mathrm{HN}-7$ & UM-SCC-81B & SCC-35 & UM-SCC-11B & & \\
\hline UM-SCC-1 & UM-SCC-87 & $S Q-31$ & UM-SCC-12 & & \\
\hline UM-SCC-9 & UM-SCC-89 & HN-SCC-104 & UM-SCC-13 & & \\
\hline UM-SCC-14A & UM-SCC-91 & $\mathrm{PCl}-5$ & UM-SCC-16 & & \\
\hline UM-SCC-14B & UM-SCC-95 & $\mathrm{PCl}-8$ & UM-SCC-17A & & \\
\hline UM-SCC-14C & UM-SCC-99 & $\mathrm{PCl}-11$ & UM-SCC-17as & & \\
\hline UM-SCC-27 & UM-SCC-100 & PCl-12 & UM-SCC-17B & & \\
\hline UM-SCC-32 & UM-SCC-101A & $\mathrm{PCl}-21$ & UM-SCC-20 & & \\
\hline UM-SCC-44 & UM-SCC-101B & PCl-32 & UM-SCC-23 & & \\
\hline UM-SCC-45 & SCC-49 & PCl-40 & UM-SCC-24 & & \\
\hline UM-SCC-47 & SCC-71 & PCl-104 & UM-SCC-25 & & \\
\hline
\end{tabular}


Table A3. (Continued).

\begin{tabular}{|c|c|c|c|c|c|}
\hline Oral cavity & Oropharynx & Hypopharynx & Larynx & Paranasal/nasal sinus & Facial skin \\
\hline UM-SCC-48 & SCC-200 & PCl-105 & UM-SCC-28 & & \\
\hline UM-SCC-49 & SQ-9G & PCl-106 & UM-SCC-36 & & \\
\hline UM-SCC-51 & HN-SCC-3 & UT-SCC-26A & UM-SCC-46 & & \\
\hline UM-SCC-55 & HN-SCC-167 & UT-SCC-26B & UM-SCC-52 & & \\
\hline UM-SCC-59 & PCl-6A & EV-SCC-10M & UM-SCC-54 & & \\
\hline UM-SCC-69 & PCI-6B & HFH-SCC-6 & UM-SCC-57 & & \\
\hline UM-SCC-73A & $\mathrm{PCl}-7$ & AMC-HN-2 & UM-SCC-66 & & \\
\hline UM-SCC-82A & PCI-9A & UD-SCC-2 & UM-SCC-67 & & \\
\hline UM-SCC-82B & PCl-9B & HNSCCUM-01T & UM-SCC-68A & & \\
\hline UM-SCC-83A & $\mathrm{PCl}-10$ & HNSCCUM-03T & UM-SCC-72 & & \\
\hline UM-SCC-83B & $\mathrm{PCl}-41$ & HNSCCUM-06N & UM-SCC-76 & & \\
\hline UM-SCC-84 & PCl-46 & HNSCCUM-07N & UM-SCC-81A & & \\
\hline UM-SCC-86 & PCl-51 & TU-212 & UM-SCC-90 & & \\
\hline UM-SCC-92 & EV-SCC-3 & TU-212 LN & UM-SCC-93 & & \\
\hline UM-SCC-96 & HFH-SCC-19 & & UM-SCC-94 & & \\
\hline UM-SCC-97 & HFH-SCC-20 & & UM-SCC-98 & & \\
\hline SCC-4 & UD-SCC-1 & & SQ-20B & & \\
\hline SCC-9 & UD-SCC-4 & & SQ-43 & & \\
\hline SCC-15 & HNSCCUM-02T & & $S Q-50$ & & \\
\hline SCC-25 & HNSCCUM-05N & & HN-SCC-28 & & \\
\hline SCC-61 & TU-158 LN & & $\mathrm{PCl}-1$ & & \\
\hline SCC-66 & TU-159 & & $\mathrm{PCl}-4 \mathrm{~A}$ & & \\
\hline SCC-68 & TU-182 & & $\mathrm{PCl}-4 \mathrm{~B}$ & & \\
\hline SCC-73 & MDA-183 & & $\mathrm{PCl}-14$ & & \\
\hline SCC-182 & JHU-20-SCC & & $\mathrm{PCl}-16$ & & \\
\hline SCC-210 & JHU-29-SCC & & $\mathrm{PCl}-17$ & & \\
\hline SCC-213 & UPCI:SCC003 & & $\mathrm{PCl}-18$ & & \\
\hline SCC-220 & UPCI:SCC036 & & $\mathrm{PCl}-19$ & & \\
\hline JSQ-3 & UPCI:SCC072 & & $\mathrm{PCl}-25$ & & \\
\hline SQ-29 & UPCI:SCC080 & & $\mathrm{PCl}-26$ & & \\
\hline SQ-38 & UPCI:SCC089 & & $\mathrm{PCl}-28$ & & \\
\hline SQ-39 & UPCI:SCC090 & & $\mathrm{PCl}-29$ & & \\
\hline HN-SCC-131 & & & PCl-35 & & \\
\hline HN-SCC-135 & & & $\mathrm{PCl}-37 \mathrm{~A}$ & & \\
\hline HN-SCC-151 & & & PCl-37B & & \\
\hline HN-SCC-294 & & & PCl-39 & & \\
\hline $\mathrm{PCl}-2$ & & & $\mathrm{PCl}-43$ & & \\
\hline $\mathrm{PCl}-3$ & & & $\mathrm{PCl}-44$ & & \\
\hline PCl-13 & & & $\mathrm{PCl}-47$ & & \\
\hline $\mathrm{PCl}-15 \mathrm{~A}$ & & & PCl-52 & & \\
\hline $\mathrm{PCl}-15 \mathrm{~B}$ & & & PCl-102 & & \\
\hline $\mathrm{PCl}-22 \mathrm{~A}$ & & & $\mathrm{PCl}-103$ & & \\
\hline PCl-22B & & & UT-SCC-6A & & \\
\hline PCl-23 & & & UT-SCC-6B & & \\
\hline PCl-24 & & & UT-SCC-8 & & \\
\hline $\mathrm{PCl}-27$ & & & UT-SCC-9 & & \\
\hline PCl-30 & & & UT-SCC-11 & & \\
\hline PCl-31 & & & UT-SCC-13 & & \\
\hline PCl-33 & & & UT-SCC-17 & & \\
\hline $\mathrm{PCl}-34$ & & & UT-SCC-19A & & \\
\hline $\mathrm{PCl}-36$ & & & UT-SCC-19B & & \\
\hline PCl-38 & & & UT-SCC-22 & & \\
\hline PCl-42 & & & UT-SCC-23 & & \\
\hline $\mathrm{PCl}-45$ & & & UT-SCC-29 & & \\
\hline PCl-50 & & & UT-SCC-34 & & \\
\hline PCl-100 & & & UT-SCC-35 & & \\
\hline PCl-101 & & & UT-SCC-38 & & \\
\hline UT-SCC-1A & & & UT-SCC-39 & & \\
\hline UT-SCC-1B & & & UT-SCC-42A & & \\
\hline UT-SCC-2 & & & UT-SCC-42B & & \\
\hline UT-SCC-5 & & & UT-SCC-49 & & \\
\hline UT-SCC-10 & & & UT-SCC-50 & & \\
\hline UT-SCC-14 & & & UT-SCC-51 & & \\
\hline UT-SCC-16A & & & EV-SCC-18 & & \\
\hline UT-SCC-16B & & & HFH-SCC-3 & & \\
\hline UT-SCC-18 & & & HFH-SCC-11 & & \\
\hline UT-SCC-20A & & & HFH-SCC-12 & & \\
\hline UT-SCC-20B & & & HFH-SCC-16 & & \\
\hline
\end{tabular}


Table A3. (Continued).

\begin{tabular}{|c|c|c|c|c|c|}
\hline Oral cavity & Oropharynx & Hypopharynx & Larynx & Paranasal/nasal sinus & Facial skin \\
\hline $\begin{array}{l}\text { UT-SCC-24A } \\
\text { UT-SCC-24B } \\
\text { UT-SCC-25 } \\
\text { UT-SCC-27 } \\
\text { UT-SCC-28 } \\
\text { UT-SCC-30 } \\
\text { UT-SCC-31 } \\
\text { UT-SCC-32 } \\
\text { UT-SCC-33 } \\
\text { UT-SCC-36 } \\
\text { UT-SCC-37 } \\
\text { UT-SCC-40 } \\
\text { UT-SCC-41 } \\
\text { UT-SCC-43A } \\
\text { UT-SCC-43B } \\
\text { UT-SCC-44 } \\
\text { UT-SCC-45 } \\
\text { UT-SCC-46A } \\
\text { UT-SCC-46B } \\
\text { UT-SCC-47 } \\
\text { UT-SCC-52 } \\
\text { UT-SCC-54A } \\
\text { UT-SCC-54B } \\
\text { UT-SCC-55 } \\
\text { EV-SCC-4 } \\
\text { EV-SCC-7 } \\
\text { EV-SCC-14M } \\
\text { EV-SCC-17P } \\
\text { EV-SCC-17M } \\
\text { EV-SCC-19P } \\
\text { EV-SCC-19M } \\
\text { HFH-SCC-4 } \\
\text { HFH-SCC-8 } \\
\text { HFH-SCC-15 } \\
\text { HFH-SCC-33 } \\
\text { AMC-HN-1 } \\
\text { AMC-HN-4 } \\
\text { AMC-HN-6 } \\
\text { UD-SCC-5 } \\
\text { UD-SCC-6 } \\
\text { TU-138 } \\
\text { TU-167 } \\
\text { TU-202 } \\
\text { CAL 33 } \\
\text { CAL 27 } \\
\text { TR 126 } \\
\text { TR 146 } \\
\text { MDA-1483 } \\
\text { T1/CUHK } \\
\text { T2/CUHK } \\
\text { JHU-12-SCC } \\
\text { UPCI:SCC016 } \\
\text { UPCI:SCC029 } \\
\text { UPCI:SCC030 } \\
\text { UPCI:SCC032 } \\
\text { UPCI:SCC040 } \\
\text { UPCI:SCC056 } \\
\text { UPCI:SCC070 } \\
\text { UPCI:SCC074 } \\
\text { UPCI:SCC075 } \\
\text { UPCI:SCC077 } \\
\text { UPCI:SCC078 } \\
\text { UPCI:SCC081 } \\
\text { UPCI:SCC084 } \\
\text { UPCI:SCC099 } \\
\text { UPCI:SCC103 } \\
\text { UPCI:SCC104 }\end{array}$ & & $x_{0}$ & $\begin{array}{l}\text { HFH-SCC-28 } \\
\text { HFH-SCC-42 } \\
\text { AMC-HN-3 } \\
\text { AMC-HN-7 } \\
\text { AMC-HN-8 } \\
\text { HNSCCUM-04N } \\
\text { TU-177 } \\
\text { TR } 131 \\
\text { TR } 138 \\
\text { 584A2 } \\
\text { MDA-886LN } \\
\text { JHU-11-SCC } \\
\text { JHU-22-SCC }\end{array}$ & 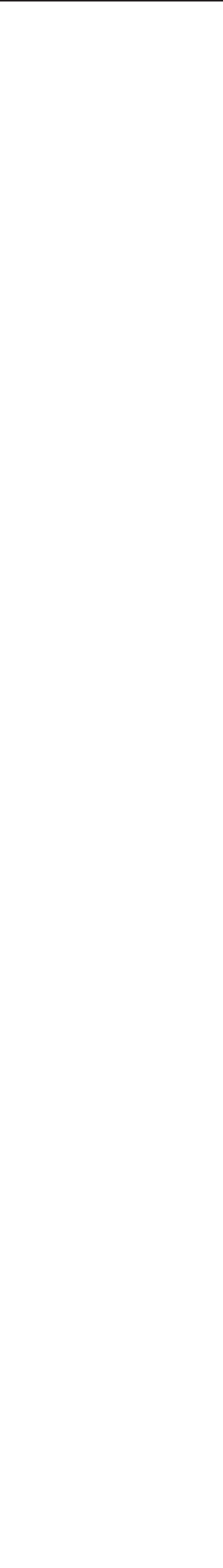 & 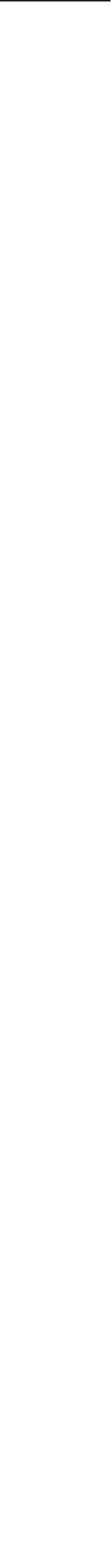 \\
\hline
\end{tabular}


Table A3. (Continued).

\begin{tabular}{|c|c|c|c|c|c|}
\hline Oral cavity & Oropharynx & Hypopharynx & Larynx & Paranasal/nasal sinus & Facial skin \\
\hline $\begin{array}{l}\text { UPCI:SCC105 } \\
\text { UPCI:SCC111 } \\
\text { UPCI:SCC114 } \\
\text { UPCI:SCC116 } \\
\text { UPCI:SCC122 } \\
\text { UPCI:SCC125 } \\
\text { UPCI:SCC131 } \\
\text { UPCI:SCC136 } \\
\text { UPCI:SCC142 } \\
\text { UPCI:SCC154 } \\
\text { UPCI:SCC172 } \\
\text { UPCI:SCC182 }\end{array}$ & & & & & \\
\hline
\end{tabular}

Note: For references, please refer to Table A1.

Table A4. Doubling times of HNSCC cell lines.

\begin{tabular}{|c|c|c|c|c|c|}
\hline Cell line & Doubling time, $\mathrm{h}$ & References & Cell line & Doubling time, $\mathrm{h}$ & References \\
\hline T3M-1 & 17 & 9 & $\mathrm{PCl}-22 \mathrm{~A}$ & 80 & 34 \\
\hline $\mathrm{HN}-1$ & 36 & 13 & $\mathrm{PCl}-22 \mathrm{~B}$ & 68 & 34 \\
\hline $\mathrm{HN}-2$ & 48 & 13 & PCl-25 & 200 & 34 \\
\hline $\mathrm{HN}-3$ & 38 & 13 & $\mathrm{PCl}-26$ & 93 & 34 \\
\hline $\mathrm{HN}-4$ & 100 & 13 & $\mathrm{PCl}-28$ & 240 & 34 \\
\hline $\mathrm{HN}-5$ & 34 & 13 & $\mathrm{PCl}-30$ & 52 & 34 \\
\hline HN-6 & 32 & 13 & $\mathrm{PCl}-33$ & 102 & 34 \\
\hline $\mathrm{HN}-6 \mathrm{Rr}$ & 30 & 15 & PCl-34 & 73 & 34 \\
\hline HN-6nl & 30 & 15 & PCl-37A & 80 & 34 \\
\hline HN-6n2 & 72 & 15 & $\mathrm{PCl}-37 \mathrm{~B}$ & 91 & 34 \\
\hline $\mathrm{HN}-7$ & 72 & 13 & PCl-38 & 82 & 34 \\
\hline $\mathrm{HN}-8$ & 170 & 13 & PCl-39 & 104 & 34 \\
\hline $\mathrm{HN}-9$ & 70 & 13 & PCI-50 & 27.3 & 38 \\
\hline $\mathrm{HN}-10$ & 60 & 13 & UT-SCC-1A & 53 & 81 \\
\hline UM-SCC-1 & 37 & 81 & UT-SCC-1B & 62 & 81 \\
\hline UM-SCC-2 & 34 & 81 & UT-SCC-2 & 32 & 81 \\
\hline UM-SCC-4 & 90 & 81 & UT-SCC-4 & 88 & 81 \\
\hline UM-SCC-5 & 34 & 81 & UT-SCC-5 & 45 & 81 \\
\hline UM-SCC-6 & 77 & 81 & UT-SCC-6A & 100 & 81 \\
\hline UM-SCC-8 & 37 & 81 & UT-SCC-6B & 91 & 81 \\
\hline UM-SCC-9 & 55 & 81 & UT-SCC-7 & 43 & 81 \\
\hline UM-SCC-10B & 36 & 81 & UT-SCC-8 & 23 & 81 \\
\hline UM-SCC-11B & 29 & 81 & UT-SCC-9 & 43 & 81 \\
\hline UM-SCC-12 & 34 & 81 & UD-SCC-1 & 32.5 & 48 \\
\hline UM-SCC-14A & 40 & 81 & UD-SCC-2 & 42 & 48 \\
\hline UM-SCC-14B & 38 & 81 & UD-SCC-3 & 31 & 48 \\
\hline UM-SCC-14C & 43 & 81 & UD-SCC-4 & 36 & 48 \\
\hline $\mathrm{PCl}-1$ & 66 & 34 & CAL 33 & 43 & 50 \\
\hline $\mathrm{PCl}-4 \mathrm{~A}$ & 58 & 7 & CAL 27 & 35 & 50 \\
\hline $\mathrm{PCl}-4 \mathrm{~B}$ & 58 & 7 & TR126 & 21 & 51 \\
\hline $\mathrm{PCl}-6 \mathrm{~A}$ & 68 & 34 & TR131 & 34 & 51 \\
\hline $\mathrm{PCl}-6 \mathrm{~B}$ & 106 & 34 & TR138 & 22 & 51 \\
\hline $\mathrm{PCl}-11$ & 124 & 34 & TR146 & 22 & 51 \\
\hline $\mathrm{PCl}-13$ & 86 & 34 & MDA-183 & 36 & 52 \\
\hline $\mathrm{PCl}-15 \mathrm{~A}$ & 126 & 34 & MDA-1483 & 36 & 52 \\
\hline $\mathrm{PCl}-15 \mathrm{~B}$ & 66 & 34 & & & \\
\hline
\end{tabular}


Table A5. HNSCC xenograft models.

\begin{tabular}{|c|c|c|c|c|c|}
\hline Nude mice & References & Nude + Cycl & References & SCID & References \\
\hline Нер2 & 82,83 & $\mathrm{PCl}-1$ & 33 & UM-SCC-11A & 84 \\
\hline Hep3 & $85-87$ & $\mathrm{PCl}-2$ & 33 & & \\
\hline $\mathrm{KB}$ & 88,89 & $\mathrm{PCl}-3$ & 33 & & \\
\hline Detroit 562 & 90,91 & $\mathrm{PCl}-4 \mathrm{~A}$ & 33 & & \\
\hline FaDu & 92,93 & $\mathrm{PCl}-4 \mathrm{~B}$ & 33 & & \\
\hline SW579 & 94 & $\mathrm{PCl}-5$ & 33 & & \\
\hline A-253 & 92 & $\mathrm{PCl}-6 \mathrm{~A}$ & 33 & & \\
\hline T3M-1 & 9 & $\mathrm{PCl}-6 \mathrm{~B}$ & 33 & & \\
\hline HLac78 & 95,96 & $\mathrm{PCl}-7$ & 33 & & \\
\hline HLac79 & 10,95 & $\mathrm{PCl}-8$ & 33 & & \\
\hline HSmC78 & 10 & PCl-9A & 33 & & \\
\hline $\mathrm{HN}-2$ & 13 & $\mathrm{PCl}-9 \mathrm{~B}$ & 33 & & \\
\hline $\mathrm{HN}-5$ & 13 & $\mathrm{PCl}-10$ & 33 & & \\
\hline $\mathrm{HN}-6$ & 13 & $\mathrm{PCl}-11$ & 33 & & \\
\hline UM-SCC-2 & 97,98 & $\mathrm{PCl}-12$ & 33 & & \\
\hline UM-SCC-3 & 97 & PCl-14 & 7 & & \\
\hline UM-SCC-4 & 7 & PCl-15A & 7 & & \\
\hline UM-SCC- 6 & 7 & $\mathrm{PCl}-15 \mathrm{~B}$ & 7 & & \\
\hline UM-SCC-7 & 7 & PCl-16 & 7 & & \\
\hline UM-SCC-10A & 7 & $\mathrm{PCl}-17$ & 7 & & \\
\hline UM-SCC-10B & 7 & $\mathrm{PCl}-18$ & 7 & & \\
\hline UM-SCC-11B & 98 & & & & \\
\hline UM-SCC-12 & 7 & & & & \\
\hline UM-SCC-14A & 7 & & & & \\
\hline UM-SCC-16 & 7 & & & & \\
\hline UM-SCC-17B & 7 & & & & \\
\hline UM-SCC-18 & 7 & & & & \\
\hline UM-SCC-19 & 7 & & & & \\
\hline UM-SCC-22B & 99 & & & & \\
\hline SCC-4 & 28 & & & & \\
\hline SCC-9 & 28 & & & & \\
\hline SCC-12 & 28 & & & & \\
\hline SCC-13 & 28 & & & & \\
\hline SCC-15 & 28 & & & & \\
\hline SCC-25 & 28 & & & & \\
\hline SCC-61 & 100 & & & & \\
\hline JSQ-3 & 101 & & & & \\
\hline SQ-20B & $102-105$ & & & & \\
\hline $\mathrm{PCl}-13$ & 7 & & & & \\
\hline PCl-52 & 106 & & & & \\
\hline UT-SCC-12A & 107 & & & & \\
\hline UT-SCC-14 & 108 & & & & \\
\hline AMC-HN-1 & 47 & & & & \\
\hline AMC-HN-2 & 47 & & & & \\
\hline AMC-HN-3 & 47 & & & & \\
\hline AMC-HN-4 & 47 & & & & \\
\hline AMC-HN-5 & 47 & & & & \\
\hline AMC-HN-6 & 47 & & & & \\
\hline AMC-HN-7 & 47 & & & & \\
\hline AMC-HN-8 & 47 & & & & \\
\hline AMC-HN-9 & 47 & & & & \\
\hline UD-SCC-1 & 48 & & & & \\
\hline UD-SCC-2 & 48 & & & & \\
\hline UD-SCC-3 & 48 & & & & \\
\hline UD-SCC-4 & 48 & & & & \\
\hline TU-138 & 109 & & & & \\
\hline CAL 27 & 50 & & & & \\
\hline CAL 33 & 50 & & & & \\
\hline TR131 & 51 & & & & \\
\hline TR138 & 51 & & & & \\
\hline TR146 & 51 & & & & \\
\hline MDA-183 & 52 & & & & \\
\hline MDA-1483 & 52 & & & & \\
\hline T1/CUHK & 55 & & & & \\
\hline T2/CUHK & 55 & & & & \\
\hline
\end{tabular}

184 Head and Neck Squamous Cell Carcinoma Cancer Cell Lines 


\section{APPENDIX REFERENCES}

1. Fjelde A. Human tumor cells in tissue culture. Cancer 1955;8:845-851.

2. Moore A, Sabachewsky L, Toolan H. Culture characteristics of four permanent lines of human cancer cells. Cancer Res 1955;15:598-602.

3. Eagle H. Propagation in a fluid medium of a human epidermoid carcinoma, strain KB. Proc Soc Exp Biol Med 1955;89:362-364.

4. Moore G, Sandberg A. Studies of a human tumor cell line with a diploid karyotype. Cancer 1964;17:170-175.

5. Peterson WJ, Stulberg C, Simpson W. A permanent heteroploid human cell line with type B glucose-6-phosphate dehydrogenase. Proc Soc Exp Biol Med 1971;136: 1187-1191.

6. Rangan S. A new human cell line (FaDu) from a hypopharyngeal carcinoma. Cancer 1972;29:117-121.

7. Lansford C, Grenman R, Bier H, et al. Head and neck cancers. In: Masters JR, Palsson B, editors. Human cell culture, Vol 2, cancer cell lines, Part 2. Dordrecht: Kluwer Academic Publishers; 1999. pp 185-255.

8. Giard DJ, Aaronson SA, Todaro GJ, et al. In vitro cultivation of human tumors: establishment of cell lines derived from a series of solid tumors. J Natl Cancer Inst 1973;51:1417-1423.

9. Okabe T, Sato N, Kondo Y, et al. Establishment and characterization of a human cancer cell line that produces human colony-stimulating factor. Cancer Res 1978; 38(11 Pt 1):3910-3917.

10. Zenner HP, Lehner W, Herrmann IF. Establishment of carcinoma cell lines from larynx and submandibular gland. Arch Otorhinolaryngol 1979;225:269-277.

11. Zenner HP, Herrmann IF, Bremer W, Stahl-Mauge C. Head and neck carcinoma models. In vivo reproduction in athymic mice and in vitro culture. Acta Otolaryngol 1983;95:371-381.

12. Nakashima T, Makishima K, Hiroto I. Establishment of a new cell line from maxillary sinus carcinoma. Ann Otol Rhinol Laryngol 1980;89(1 Pt 1):24-28.

13. Easty D, Easty G, Carter R, Monaghan P, Butler L. Ten human carcinoma cell lines derived from squamous carcinomas of the head and neck. Br J Cancer 1981;43: $772-785$.

14. Hauser-Urfer IH, Stauffer J. Comparative chromosome analysis of nine squamous cell carcinoma lines from tumors of the head and neck. Cytogenet Cell Genet 1985; 39:35-39

15. Easty DM, Easty GC, Carter RL, Monaghan P, Pittam MR, James T. Five human tumour cell lines derived from a primary squamous carcinoma of the tongue, two subsequent local recurrences and two nodal metastases. Br J Cancer 1981;44:363-370.

16. Krause C, Carey T, Ott R, Hurbis C, McClatchey K, Regezi J. Human squamous cell carcinoma. Establishment and characterization of new permanent cell lines. Arch Otolaryngol 1981;107:703-710.

17. Buchhagen DL, Worsham MJ, Dyke DL, Carey TE. Two regions of homozygosity on chromosome $3 p$ in squamous cell carcinoma of the head and neck: comparison with cytogenetic analysis. Head Neck 1996;18: 529-537.

18. Kelker W, Van Dyke DL, Worsham MJ, et al. Loss of $18 \mathrm{q}$ and homozygosity for the DCC locus: possible markers for clinically aggressive squamous cell carcinoma. Anticancer Res 1996;16:2365-2372.

19. Grenman R, Carey TE, McClatchey $\mathrm{KD}$, et al. In vitro radiation resistance among cell lines established from patients with squamous cell carcinoma of the head and neck. Cancer 1991;67:2741-2747.

20. Roa RA, Carey TE, Passamani PP, et al. DNA content of human squamous cell carcinoma cell lines. Analysis by flow cytometry and chromosome enumeration. Arch Otolaryngol 1985;111:565-575.

21. Van Dyke DL, Worsham MJ, Benninger MS, et al. Recurrent cytogenetic abnormalities in squamous cell carcinomas of the head and neck region. Genes Chromosomes Cancer 1994;9:192-206.

22. Somers KD, Merrick MA, Lopez ME, Incognito LS, Schechter GL, Casey G. Frequent p53 mutations in head and neck cancer. Cancer Res 1992;52:5997-6000.

23. Carey TE, Van Dyke DL, Worsham MJ, et al. Characterization of human laryngeal primary and metastatic squamous cell carcinoma cell lines UM-SCC-17A and UM-SCC-17B. Cancer Res 1989;49:6098-107.

24. Frank CJ, McClatchey KD, Devaney KO, Carey TE. Evidence that loss of chromosome $18 \mathrm{q}$ is associated with tumor progression. Cancer Res 1997;57:824-827.

25. Carey TE, Kimmel KA, Schwartz DR, Richter DE, Baker SR, Krause CJ. Antibodies to human squamous cell carcinoma. Otolaryngol Head Neck Surg 1983;91: 482-491.

26. Carey TE, Van Dyke DL, Worsham MJ. Nonrandom chromosome aberrations and clonal populations in head and neck cancer. Anticancer Res 1993;13:25612567.

27. Akervall J, Guo X, Qian C, et al. Genetic and expression profiles of squamous cell carcinoma of the head and neck correlate with cisplatin sensitivity and resistance in cell lines and patients. Clin Cancer Res 2004;10: 8204-8213.

28. Rheinwald J, Beckett M. Tumorigenic keratinocyte lines requiring anchorage and fibroblast support cultured from human squamous cell carcinomas. Cancer Res 1981;41:1657-1663.

29. Cowan JM, Beckett MA, Ahmed-Swan S, Weichselbaum RR. Cytogenetic evidence of the multistep origin of head and neck squamous cell carcinomas. J Natl Cancer Inst 1992;84:793-797.

30. Weichselbaum RR, Dahlberg W, Beckett M, et al. Radiation-resistant and repair-proficient human tumor cells may be associated with radiotherapy failure in headand neck-cancer patients. Proc Natl Acad Sci U S A 1986; 83:2684-2688.

31. Weichselbaum RR, Beckett MA, Vijayakumar S, et al. Radiobiological characterization of head and neck and sarcoma cells derived from patients prior to radiotherapy. Int J Radiat Oncol Biol Phys 1990;19:313-319.

32. Dunphy EJ, Beckett MA, Thompson LH, Weichselbaum RR. Expression of the polymorphic human DNA repair gene $X R C C 1$ does not correlate with radiosensitivity in the cells of human head and neck tumor cell lines. Radiat Res 1992;130:166-70.

33. Heo DS, Snyderman C, Gollin SM, et al. Biology, cytogenetics, and sensitivity to immunological effector cells of new head and neck squamous cell carcinoma lines. Cancer Res 1989;49:5167-5175.

34. Snyderman CH, Klapan I, Milanovich M, et al. Comparison of in vivo and in vitro prostaglandin E2 production by squamous cell carcinoma of the head and neck. Otolaryngol Head Neck Surg 1994;111:189-196.

35. Sacchi M, Klapan I, Johnson JT, Whiteside TL. Antiproliferative effects of cytokines on squamous cell carcinoma. Arch Otolaryngol Head Neck Surg 1991;117: 321-326.

36. Yasumura S, Weidmann E, Hirabayashi H, Johnson JT, Herberman RB, Whiteside TL. HLA restriction and T-cell-receptor $\mathrm{V} \beta$ gene expression of cytotoxic $\mathrm{T}$ lymphocytes reactive with human squamous-cell carcinoma of the head and neck. Int J Cancer 1994;57:297305.

37. Yin XY, Donovan-Peluso M, Whiteside TL, et al. Gene amplification and gene dosage in cell lines derived from squamous cell carcinoma of the head and neck [see 
comment]. Genes Chromosomes Cancer 1991;3:443454.

38. Yasumura S, Hirabayashi H, Schwartz DR, et al. Human cytotoxic T-cell lines with restricted specificity for squamous cell carcinoma of the head and neck. Cancer Res 1993;53:1461-1468.

39. Sung MW, Yasumura S, Johnson JT, Van Dongen GA, Whiteside TL. Natural killer (NK) cells as effectors of antibody-dependent cytotoxicity with chimeric antibodies reactive with human squamous-cell carcinomas of the head and neck. Int J Cancer 1995;61:864-872.

40. Nagashima S, Mailliard R, Kashii Y, et al. Stable transduction of the interleukin-2 gene into human natural killer cell lines and their phenotypic and functional characterization in vitro and in vivo. Blood 1998; 91:3850-3861.

41. Soukka T, Salmi M, Joensuu H, et al. Regulation of CD44v6-containing isoforms during proliferation of normal and malignant epithelial cells. Cancer Res 1997;57: 2281-2289.

42. Johansson N, Airola K, Grenman R, Kariniemi AL, Saarialho-Kere U, Kahari VM. Expression of collagenase-3 (matrix metalloproteinase-13) in squamous cell carcinomas of the head and neck. Am J Pathol 1997;151: 499-508.

43. Salo A, Servomaa K, Kiuru A, et al. The bcl-2 gene status of human head and neck cancer cell lines. Acta Otolaryngol Suppl 1997;529:233-236.

44. Elomaa L, Joensuu H, Kulmala J, Klemi P, Grenman R. Squamous cell carcinoma is highly sensitive to Taxol, a possible new radiation sensitizer. Acta Otolaryngol 1995;115:340-344.

45. Worsham MJ, Wolman SR, Carey TE, Zarbo RJ, Benninger MS, Van Dyke DL. Common clonal origin of synchronous primary head and neck squamous cell carcinomas: analysis by tumor karyotypes and fluorescence in situ hybridization [see comment]. Hum Pathol 1995;26:251-261.

46. Worsham MJ, Benninger MJ, Zarbo RJ, Carey TE, Van Dyke DL. Deletion 9p22-pter and loss of $\mathrm{Y}$ as primary chromosome abnormalities in a squamous cell carcinoma of the vocal cord. Genes Chromosomes Cancer 1993;6:58-60.

47. Kim SY, Chu KC, Lee HR, Lee KS, Carey TE. Establishment and characterization of nine new head and neck cancer cell lines. Acta Otolaryngol 1997;117:775784.

48. Ballo H, Koldovsky P, Hoffmann T, et al. Establishment and characterization of four cell lines derived from human head and neck squamous cell carcinomas for an autologous tumor-fibroblast in vitro model. Anticancer Res 1999;19:3827-3836.

49. Beckhardt RN, Kiyokawa N, Xi L, et al. HER-2/neu oncogene characterization in head and neck squamous cell carcinoma. Arch Otolaryngol Head Neck Surg 1995; 121:1265-1270.

50. Gioanni J, Fischel JL, Lambert JC, et al. Two new human tumor cell lines derived from squamous cell carcinomas of the tongue: establishment, characterization and response to cytotoxic treatment. Eur J Cancer Clin Oncol 1988;24:1445-1455.

51. Rupniak HT, Rowlatt C, Lane EB, et al. Characteristics of four new human cell lines derived from squamous cell carcinomas of the head and neck. J Natl Cancer Inst 1985;75:621-635.

52. Sacks PG, Parnes SM, Gallick GE, et al. Establishment and characterization of two new squamous cell carcinoma cell lines derived from tumors of the head and neck. Cancer Res 1988;48:2858-2866.

53. Weber RS, Pathak S, Frankenthaler R, Gallick GE, Sacks PG. Effect of epidermal growth factor (EGF) on a newly established head and neck squamous carci- noma cell line. Otolaryngol Head Neck Surg 1988;99. 567-573.

54. Sacks PG, Oke V, Amos B, Vasey T, Lotan R. Modulation of growth, differentiation and glycoprotein synthesis by $\beta$-all-trans retinoic acid in a multicellular tumor spheroid model for squamous carcinoma of the head and neck. Int J Cancer 1989;44:926-933.

55. Chew EC, King WW, Hou HJ, Yam HF. Establishment and characterization of two new cell lines derived from squamous cell carcinoma of the tongue in Chinese patients. Anticancer Res 1992;12:1627-1633.

56. Sturgis EM, Sacks PG, Masui H, Mendelsohn J, Schantz SP. Effects of antiepidermal growth factor receptor antibody 528 on the proliferation and differentiation of head and neck cancer. Otolaryngol Head Neck Surg 1994;111:633-643.

57. Griffon-Etienne G, Merlin JL, Marchal C. Evaluation of Taxol in head and neck squamous carcinoma multicellular tumor spheroids. Anticancer Drugs 1997;8:4855.

58. Huang X, Gollin SM, Raja S, Godfrey TE. High-resolution mapping of the 11q13 amplicon and identification of a gene, TAOS1, that is amplified and overexpressed in oral cancer cells. Proc Natl Acad Sci U S A 2002;99: 11369-11374.

59. White JS, Weissfeld JL, Ragin CCR, et al. The influence of clinical and demographic risk factors on the establishment of head and neck squamous cell carcinoma cell lines (in press).

60. Saunders WS, Shuster M, Huang X, et al. Chromosomal instability and cytoskeletal defects in oral cancer cells. Proc Natl Acad Sci U S A 2000;97:303-308.

61. Virgilio L, Shuster M, Gollin SM, et al. FHIT gene alterations in head and neck squamous cell carcinomas. Proc Natl Acad Sci U S A 1996;93:9770-9775.

62. Ferris RL, Martinez I, Sirianni N, et al. Human papillomavirus-16 associated squamous cell carcinoma of the head and neck (SCCHN): a natural disease model provides insights into viral carcinogenesis. Eur J Cancer 2005;41:807-815.

63. Hewitt C, Wilson P, McGlinn E, et al. DLC1 is unlikely to be a primary target for deletions on chromosome arm 8p22 in head and neck squamous cell carcinoma. Cancer Lett 2004;209:207-213.

64. Hoffelder DR, Luo L, Burke NA, Watkins SC, Gollin SM, Saunders WS. Resolution of anaphase bridges in cancer cells. Chromosoma 2004;112:389-397.

65. Ishwad CS, Shuster M, Bockmuhl U, et al. Frequent allelic loss and homozygous deletion in chromosome band 8p23 in oral cancer. Int J Cancer 1999;80: $25-31$.

66. Reing JE, Gollin SM, Saunders WS. The occurrence of chromosome segregational defects is an intrinsic and heritable property of oral squamous cell carcinoma cell lines. Cancer Genet Cytogenet 2004;150:57-61.

67. Reshmi SC, Saunders WS, Kudla DM, Ragin CR, Gollin SM. Chromosomal instability and marker chromosome evolution in oral squamous cell carcinoma. Genes Chromosomes Cancer 2004;41:38-46.

68. Quintyne NJ, Reing JE, Hoffelder DR, Gollin SM, Saunders WS. Spindle multipolarity is prevented by centrosomal clustering. Science 2005;307:127-129.

69. Ragin CC, Reshmi SC, Gollin SM. Mapping and analysis of HPV16 integration sites in a head and neck cancer cell line. Int J Cancer 2004;110:701-709.

70. Sun PC, Uppaluri R, Schmidt AP, et al. Transcript map of the 8p23 putative tumor suppressor region. Genomics 2001;75:17-25.

71. Liggett WH Jr, Sewell DA, Rocco J, Ahrendt SA, Koch W, Sidransky D. p16 and p16 $\beta$ are potent growth suppressors of head and neck squamous carcinoma cells in vitro. Cancer Res 1996;56:4119-4123. 
72. Scher RL, Koch WM, Richtsmeier WJ. Induction of the intercellular adhesion molecule (ICAM-1) on squamous cell carcinoma by interferon $\gamma$. Arch Otolaryngol Head Neck Surg 1993;119:432-438.

73. Scher RL, Saito W, Dodge RK, Richtsmeier WJ, Fine RL. Fenretinide-induced apoptosis of human head and neck squamous carcinoma cell lines. Otolaryngol Head Neck Surg 1998;118:464-471.

74. Scher RL, Carras A, Schwab D, Richtsmeier WJ, Koch WM. Interferon $\gamma$ enhances lymphokine-activated killer cell adhesion but not lysis of head and neck squamous cell carcinoma. Arch Otolaryngol Head Neck Surg 1995;121:1271-1275.

75. Yin XY, Smith ML, Whiteside TL, Johnson JT, Herberman RB, Locker J. Abnormalities in the $p 53$ gene in tumors and cell lines of human squamous-cell carcinomas of the head and neck. Int J Cancer 1993;54:322327.

76. Hauser U, Balz V, Carey TE, et al. Reliable detection of p53 aberrations in squamous cell carcinomas of the head and neck requires transcript analysis of the entire coding region. Head Neck 2002;24:868-873.

77. Bradford CR, Zacks SE, Androphy EJ, Gregoire L, Lancaster WD, Carey TE. Human papillomavirus DNA sequences in cell lines derived from head and neck squamous cell carcinomas. Otolaryngol Head Neck Surg 1991;104:303-310.

78. Telmer CA, An J, Malehorn DE, et al. Detection and assignment of TP53 mutations in tumor DNA using peptide mass signature genotyping. Hum Mutat 2003;22: 158-165.

79. Grenman R, Burk D, Virolainen E, et al. Clonogenic cell assay for anchorage-dependent squamous carcinoma cell lines using limiting dilution. Int J Cancer 1989; 44:131-136.

80. Grenman R, Burk D, Virolainen E, Wagner JG, Lichter AS, Carey TE. Radiosensitivity of head and neck cancer cells in vitro. A 96-well plate clonogenic cell assay for squamous cell carcinoma. Arch Otolaryngol Head Neck Surg 1988;114:427-431.

81. Pekkola-Heino K, Joensuu H, Klemi P, Grenman R. Relation of DNA ploidy and proliferation rate to radiation sensitivity in squamous carcinoma cell lines. Arch Otolaryngol Head Neck Surg 1994;120:750-754.

82. Eriksson D, Joniani HM, Sheikholvaezin A, et al. Combined low dose radio- and radioimmunotherapy of experimental HeLa Hep 2 tumours. Eur J Nucl Med Mol Imaging 2003;30:895-906.

83. Snook DE, Rowlinson-Busza G, Sharma HL, Epenetos AA. Preparation and in vivo study of 124I-labelled monoclonal antibody H17E2 in a human tumour xenograft model. A prelude to positron emission tomography (PET). Br J Cancer Suppl 1990;10:89-91.

84. Ricker J. 2-methoxyestradiol inhibits hypoxia-inducible factor $1 \alpha$, tumor growth, and angiogenesis and augments paclitxel efficacy in head and neck squamous cell carcinoma. Clin Cancer Res 2004;10:8665-8673.

85. Allalunis-Turner MJ, Lee FY, Siemann DW. Comparison of glutathione levels in rodent and human tumor cells grown in vitro and in vivo. Cancer Res 1988;48: $3657-3660$

86. Allalunis-Turner MJ, Siemann DW. Recovery of cell subpopulations from human tumour xenografts following dissociation with different enzymes. $\mathrm{Br} \mathrm{J}$ Cancer 1986;54:615-622.

87. Ossowski L, Russo H, Gartner M, Wilson EL. Growth of a human carcinoma (HEp3) in nude mice: rapid and efficient metastasis. J Cell Physiol 1987;133:288-296.

88. Iida M, Kojima H, Miyazaki H, Manome Y. Enhancement of cyclophosphamide sensitivity in squamous cell carcinoma transfected with cytochrome P-450 2B1. Am J Otolaryngol 2005;26:22-27.
89. Jahng J, Choi S, Cha M, Kim N, Hwang S, Lee J. Serotonin transporter mRNA expression in the dorsal raphe nucleus of a tumor bearing mouse. 2005;37:65-69.

90. Hambek M, Solbach C, Schnuerch HG, et al. Tumor necrosis factor $\alpha$ sensitizes low epidermal growth factor receptor (EGFR)-expressing carcinomas for anti-EGFR therapy. Cancer Res 2001;61:1045-1049.

91. Ning S, Shui C, Khan WB, Benson W, Lacey DL, Knox SJ. Effects of keratinocyte growth factor on the proliferation and radiation survival of human squamous cell carcinoma cell lines in vitro and in vivo. Int $J$ Radiat Oncol Biol Phys 1998;40:177-187.

92. Azrak RG, Cao S, Slocum HK, et al. Therapeutic synergy between irinotecan and 5-fluorouracil against human tumor xenografts. Clin Cancer Res 2004;10:11211129 .

93. Hessel F, Petersen C, Zips D, et al. Impact of increased cell loss on the repopulation rate during fractionated irradiation in human $\mathrm{FaDu}$ squamous cell carcinoma growing in nude mice. Int J Radiat Biol 2003;79:479486.

94. Fogh J, Fogh JM, Orleo T. One hundred and twentyseven cultured human tumor cell lines producing tumors in nude mice. J Natl Cancer Inst 1977;59:221226.

95. Homann B, Zenner HP, Schauber J, Ackermann R. Tumor cells carried through autotransfusion. Are these cells still malignant? Acta Anaesthesiol Belg 1984;35(Suppl): $51-59$.

96. Kumazawa H, Koldovsky P, Kurten C, Vosteen KH. Effect of lymphokine-activated killer cells on head and neck tumours in nude mouse model. Acta Otolaryngol 1989;108:317-324.

97. Carey TE. Establishment of epidermoid carcinoma cell lines. In: Wittes RE, editor. Head and neck cancer. London: Wiley; 1985. pp 287-314.

98. Wahl RL, Kimmel KA, Beierwaltes WH, Carey TE. Radioimmunodiagnosis of human-derived squamous cell carcinoma. Hybridoma 1987;6:111-119.

99. Shalinsky DR, Bischoff ED, Lamph WW, et al. A novel retinoic acid receptor-selective retinoid, ALRT1550, has potent antitumor activity against human oral squamous carcinoma xenografts in nude mice. Cancer Res 1997;57:162-168.

100. Khodarev NN, Beckett M, Labay E, Darga T, Roizman $\mathrm{B}$, Weichselbaum RR. STAT1 is overexpressed in tumors selected for radioresistance and confers protection from radiation in transduced sensitive cells. Proc Natl Acad Sci U S A 2004;101:1714-1719.

101. Xu L, Pirollo KF, Chang EH. Transferrin-liposomemediated p53 sensitization of squamous cell carcinoma of the head and neck to radiation in vitro. Hum Gene Ther 1997;8:467-475.

102. Chmura SJ, Dolan ME, Cha A, Mauceri HJ, Kufe DW, Weichselbaum RR. In vitro and in vivo activity of protein kinase $\mathrm{C}$ inhibitor chelerythrine chloride induces tumor cell toxicity and growth delay in vivo. Clin Cancer Res 2000;6:737-742.

103. Hanna NN, Mauceri HJ, Wayne JD, Hallahan DE, Kufe DW, Weichselbaum RR. Virally directed cytosine deaminase/5-fluorocytosine gene therapy enhances radiation response in human cancer xenografts. Cancer Res 1997;57:4205-4209.

104. Kasid U, Pfeifer A, Brennan T, et al. Effect of antisense c-raf- 1 on tumorigenicity and radiation sensitivity of a human squamous carcinoma. Science 1989;243:13541356.

105. Mauceri HJ, Hanna NN, Wayne JD, Hallahan DE, Hellman S, Weichselbaum RR. Tumor necrosis factor $\alpha$ $(T N F-\alpha)$ gene therapy targeted by ionizing radiation selectively damages tumor vasculature. Cancer Res 1996; 56:4311-4314. 
106. Nagashima S, Reichert TE, Kashii Y, Suminami Y, Chikamatsu K, Whiteside TL. In vitro and in vivo characteristics of human squamous cell carcinoma of the head and neck cells engineered to secrete interleukin-2. Cancer Gene Ther 1997;4:366-376.

107. Jaaskela-Saari HA, Kairemo KJ, Ramsay HA, Grenman R. Squamous cell cancer cell lines: sensitivity to bleomycin and suitability for animal xenograft studies. Acta Otolaryngol Suppl 1997;529:241244 .
108. Zips D, Hessel F, Krause M, et al. Impact of adjuvant inhibition of vascular endothelial growth factor receptor tyrosine kinases on tumor growth delay and local tumor control after fractionated irradiation in human squamous cell carcinomas in nude mice. Int J Radiat Oncol Biol Phys 2005;61:908-914.

109. Liu TJ, Wang M, Breau RL, et al. Apoptosis induction by E2F-1 via adenoviral-mediated gene transfer results in growth suppression of head and neck squamous cell carcinoma cell lines. Cancer Gene Ther 1999;6:163-171. 